\title{
Diferenças fatais: suicídio, raça e trabalho forçado nas Américas*
}

\author{
Fatal differences: Suicide, race, and forced labor in the Americas
}

\section{Marc A. Hertzman**}

Resumo: Neste ensaio, examino a relação entre raça e suicídio nas Américas. Mostro como as ideias sobre suicídio ajudaram a gerar e reforçar várias formas de diferença racial e demonstro como as ideias coloniais sobreviveram por muito tempo após a independência e a abolição da escravidão, geralmente em novas forma $A$ historiografia existente sobre suicídio enfatiza respostas morais, religiosas e médicolegais à autodestruição. Menos atenção foi dada à raça ou ao fato brutal, amplamente reconhecido (embora raramente discutido em profundidade) pelos estudiosos da escravidão, que a servidão forçada também transformou o suicídio em uma questão essencialmente econômica - uma ameaça aos resultados dos plantadores e comerciantes e uma ameaça à produção. Â medida que a escravidão e o trabalho forçado se tornavam sistemas de valores globais dominantes que determinavam quem contava como humano, a capacidade de perecer pelas próprias mãos se tornou um meio de vencer essa determinação. Em algum momento, histórias excepcionais de suicídio heroico de mártires nativos ou negros passaram a fazer parte de narrativas nacionais, mas esse processo dependia da dissociação entre autodestruição e produção econômica, o que ajudou a transformar atos, antes vistos como ameaça às fundações coloniais, em histórias de sacrifício e nascimento nacional. Com o tempo, e apesar das mudanças significativas, a autodestruição funcionou consistentemente como um marcador duradouro da diferenciação racial.

Palavras-chave: Suicídio. Escravidão. Brasil. América Latina. Zumbi.

Abstract: This essay examines the relationship between race and suicide in the Americas. I show how ideas about suicide helped generate and reinforce multiple forms of racial difference and demonstrate how colonial ideas survived long after independence and the abolition of slavery, often in new forms. The extant historiography on suicide emphasizes moral, religious, and medico-legal responses

* Tradução: Mariângela de Mattos Nogueira. Publicado originalmente em inglês, com o título Fatal differences: Suicide, race, and forced labor in the Americas, na American Historical Review, v. 122, n. 2, p. 317-345, 2017.

** Associate Professor e Director of Undergraduate Studies, no Departamento de História da University of Illinois, Urbana-Champaign. E-mail: hertzman@illinois.edu. ORCID: https://orcid.org/0000-00018754-3494. Seu primeiro livro, Making samba: A new history of race and music in Brazil (Duke University Press, 2013), ganhou menção honrosa pelo Prêmio Bryce Wood, concedido anualmente ao melhor trabalho sobre a América Latina em Ciências Humanas e Sociais. Gostaria de agradecer aos participantes do workshop do Departamento de História da UIUC e aos colegas de Illinois, incluindo Ikuko Asaka, Jim Brennan, Antoinette Burton, Clare Crowston, Jerry Davila, Dara Goldman, Glen Goodman, Fred Hoxie, Silvia Escanilla Huerta, Nils Jacobsen, Diane Koenker, Craig Koslofsky, Harry Liebersohn, John Marquez, Bob Morrissey, Dana Rabin, Mike Silvers, e Mark Steinberg. Em outras instituições, agradeço a Ana Lucia Araujo, Ned Blackhawk, Celso Castilho, Camillia Cowling, Julia Cuervo-Hewitt, Nicanor Dominguez, Rebecca Earle, Flávio Gomes, Frances Hagopian, Russell Lohse, Yuko Miki, Jeff Ostler, Lara Putnam, Matthew Restall, Terri Snyder, Zeb Tortorici, Sarah Townsend e Brandi Waters. Gostaria também de agradecer ao parecerista anônimo de AHR's e seus editores, pelos estimulantes comentários e críticas, e a Halley Juvik por apresentar-me Cahuide. Versões deste trabalho foram apresentadas nas Universidades de Harvard, Penn State e Wesleyan. 
to self-destruction. Less attention has been paid to race or to the brutal fact, widely acknowledged (though rarely discussed in depth) by scholars of slavery, that forced servitude also made suicide a quintessentially economic issue-a threat to planters' and traders' bottom line and a threat to production. As slavery and forced labor became dominant global value systems that determined who counted as human, the ability to perish by one's own hand became a means for making that determination. Eventually, exceptional stories of heroic suicide by native or black martyrs became part of national narratives, but that process depended on the decoupling of selfdestruction and economic production, which helped turn acts once seen as threats to colonial foundations into stories of sacrifice and national birth. Over time, and despite significant changes, self-destruction consistently functioned as a durable marker of racial differentiation.

Keywords: Suicide; Slavery; Brazil; Latin America; Zumbi.

Numa batalha crucial durante a invasão europeia dos Andes, soldados nativos capturaram Sacsayhuamán, uma fortaleza das tropas espanholas em Cuzco. Os conquistadores acabaram protegendo a estrutura icônica, depois de uma batalha feroz e apesar dos esforços heroicos de um guerreiro inca, particularmente corajoso, o Cahuide. De acordo com um manuscrito apócrifo de 1539, que narra as façanhas espanholas no Peru, à medida que os europeus chegavam a Sacsayhuamán, Cahuide vislumbrava "o destino" de dar cabo de sua vida: "Incapaz de suportar a visão de [espanhóis] ultrapassando a fortaleza ... [ele] saltou do topo da fortaleza". ${ }^{1}$ Dois séculos depois, Sebastião da Rocha Pita, autor luso-americano, descreveu cena semelhante em Palmares, a famosa comunidade de escravos fugitivos (quilombo), no que é hoje o nordeste do Brasil. Rocha Pita não estava presente à batalha, que ocorrera em 1695, mas, mesmo assim, narrou em primeira pessoa: "Não querendo ser nossos cativos ou morrer por nossas espadas" os quilombolas, liderados por Zumbi, "jogaram-se [de um pico próximo]." Com "esse tipo de morte", ele acrescentou, "mostraram que não tinham amor pela vida de escravos e não queriam ser derrotados em nossas mãos". ${ }^{2}$

As grandes semelhanças entre essas duas histórias sugerem as aparentes qualidades universais do suicídio, muitas vezes construído nos tratamentos

Relación del sitio del Cuzco y principio de las guerras civiles del Peru hasta la muerte de Diego de Almagro, 1535-1539 [1539], Biblioteca Nacional de España, sala de MS., J. 130, reproduzido em Varias relaciones del Peru y Chile; y conquista de la isla de Santa Catalina, 1535 a 1658. Madrid: [s.n.], 1879. p. 32-33. Salvo indicação em contrário, as traduções são minhas.

2 PITA, Sebastião da Rocha. História da América portuguesa. São Paulo: Itatiaia USP, 1976. p. 219. A obra original data de 1730 . 
europeístas como um ato essencialmente humano. ${ }^{3} \mathrm{Na}$ América Latina, essa aparente universalidade é especialmente atraente.

As histórias de dois indivíduos, em diferentes partes da região, envolvidos numa luta sangrenta contra o colonialismo, sugerem um poderoso elo potencial de uma divisão acadêmica familiar. Os historiadores costumam dividir as regiões supostamente negras (Brasil e Caribe) das regiões nativas (nações de língua espanhola, rotuladas como indígenas ou mestiças), uma prática que reflete algumas realidades demográficas, mas que é também problemática. ${ }^{4}$ Além de tornar a branquitude uma presença estável e silenciosa em ambas as esferas, a divisão - que Barbara Weinstein chama de divisão "afro" - "indígena" - oculta histórias que cruzam linhas regionais e linguísticas e marginalizam grupos que não se encaixam no esquema binário. ${ }^{5}$

Uma abordagem universalista do suicídio pode tratar histórias como a de Cahuide e de Zumbi como um passo além da divisão afro-indígena. No entanto, o suicídio não é, de fato, um fenômeno universal, transcultural, mas um ato a que múltiplos significados são atribuídos, em todo o mundo. Além disso, os colonialistas europeus e euro-americanos muitas vezes transformaram o suicídio num veículo de geração e reforço da diferença racial, por sua vez, frequentemente, ligado a fronteiras e distinções geográficas e epistemológicas. ${ }^{6}$ Como a embriaguez, a homossexualidade e um número de ações definidas como criminosas, o suicídio foi racializado e patologizado ao longo do tempo. Mas ele é único por sua relação com o significado e poder de dar e receber vida. Esse poder pertence a Deus? Aos senhores? Pagãos ou escravos teriam esse poder? No centro dessas questões está o privilégio da individualidade e o direito de ser considerado humano.

Para entender a relação entre autodestruição e raça, podemos perguntar, parafraseando Terri Snyder, o que um conjunto de atores históricos (neste caso,

3 Por exemplo, Baechler escreveu, "A humanidade é uma e... suicídio é uma solução universalmente empregada em certas situações típicas”. BAECHLER, Jean. Suicides. New York: Basic Books, 1979. p. 39. Traduzido por Barry Cooper. Também: MINOIS, Georges. History of suicide: Voluntary death in western culture. Baltimore: Johns Hopkins University Press, 2001. p. 2-3, 268. Traduzido por Lydia G. Cochrane. Embora consciente do fato de que a palavra "suicídio" surgiu na Inglaterra do final do século XVII, para simplificar usarei o termo em todo o texto.

4 Como este artigo aborda pessoas e lugares que usavam rótulos e categorias raciais distintos, muitos dos quais mudaram ao longo do tempo, é necessária uma forma abreviada. Por isso, geralmente aplico termos mais reconhecíveis para o público dos Estados Unidos. Embora consciente da suprema inadequação e da natureza problemática do termo "índio", ocasionalmente o emprego para referir os Primeiros Povos das Américas, especialmente para refletir a linguagem usada em fontes primárias.

5 WEINSTEIN, Barbara. Erecting and erasing boundaries: Can we combine the 'Indo' and the 'Afro' in Latin American studies? Estudios Interdisciplinarios de América Latina y el Caribe, v. 19, n. 1, p. 129-144, 2008.

6 Uso "América" e "Américas" para me referir ao hemisfério como um todo. 
principalmente brancos, principalmente homens) - escritores, conquistadores, clérigos, viajantes, cirurgiões, traficantes de escravos, senhores de escravos, acadêmicos - falaram, quando falaram, sobre suicídio. ${ }^{7}$ Seus diálogos literais e figurativos ocorreram em três eras. Durante o período colonial (por volta de 1500 à década de 1820), os observadores brancos europeus e euro-americanos atribuíram significados distintos à autodestruição de africanos e de nativos americanos, definindo o primeiro como um ato patológico e um ataque à ordem econômica e o segundo, como sinal de fragilidade indígena. Os discursos pós-independência continuaram a enfatizar a diferença racial, embora muitas vezes com novo enfoque. Figuras coloniais de "nativos agonizantes" fundiram-se facilmente em paisagens póscoloniais, mas o suicídio negro ocorreu mais desconfortavelmente em discursos nacionais emergentes, moldados por temores de rebelião de escravos e dos potenciais efeitos econômicos e sociais da emancipação. Consequentemente, a autodestruição negra foi frequentemente abandonada, especialmente nos debates sobre a abolição na América Latina - um forte contraste com o Atlântico Norte, onde os ativistas antiescravistas frequentemente empregavam o suicídio como uma arma política efetiva.

Na segunda metade do século XIX, o suicídio continuou a marcar a diferença racial, embora mais uma vez os termos da discussão tenham mudado. Durante anos após suas mortes, as histórias de Cahuide e Zumbi praticamente desapareceram do registro escrito. ${ }^{8}$ No final do século XIX, ambos ressurgiram nas histórias nacionais que abraçavam discursivamente grupos não brancos, embora os marginalizasse de forma concreta. Quando a escravidão chegou ao fim, parte da ansiedade anteriormente dirigida aos escravos negros foi transferida para os trabalhadores asiáticos contratados. Tudo isso preparou o cenário para que no final do século XIX e início do XX o suicídio se tornasse um objeto cada vez mais recorrente no estudo acadêmico, em toda a América. Alguns especialistas argumentaram que a civilização, antes quase sempre entendida como um refúgio das "manias" suicidas de pessoas retrógradas, era exatamente o oposto: uma condição que, em sua encarnação moderna, criou tensões que levaram os brancos a se matar em números alarmantes, mesmo quando os grupos, muitas vezes (e negativamente) associados ao suicídio, foram repentinamente retratados como tudo, menos como afeitos a ele. Os não brancos - explicavam os estudiosos - eram muito atrasados para entender e,

7 SNYDER, Terri L. What historians talk about when they talk about suicide: The view from early modern British North America. History Compass, v. 5, n. 2, p. 658-674, 2007.

8 Não há praticamente nenhum estudo acadêmico sobre Cahuide. As referências a Zumbi são anotadas a seguir. 
mais ainda, para sucumbir às pressões da sociedade moderna. Outros especialistas vacilaram, reconhecendo a suposta epidemia de suicídio branco, embora ainda associando a autodestruição a grupos não brancos. Através dessas mudanças e reversões, o suicídio funcionava como marcador e metáfora da diferença racial, como um mecanismo discursivo que ajudava a elevar os brancos em detrimento dos não brancos, e como uma ferramenta capaz de agrupar grupos não brancos em uma única massa ou dividi-los em subconjuntos distintos.

Antes da década de 1980, poucos historiadores escreveram sobre o suicídio. Após a publicação de Le suicide, em 1897, por Emile Durkheim, o assunto era atribuído principalmente a cientistas sociais. ${ }^{9}$ Os primeiros estudos históricos, escritos principalmente por europeus, mapearam como o suicídio se tornou cada vez mais "secularizado" ao longo do tempo. O que era uma preocupação principalmente religiosa no início da era moderna passou paulatinamente ao olhar de médicos, juristas e estados. ${ }^{9}$

Outros autores têm argumentado, desde então, que a secularização implica uma falsa teleologia para o que era um processo mais complexo, abrangendo um conjunto "híbrido" de perspectivas morais e médico-legais. ${ }^{10}$

A literatura europeia moldou um pequeno, mas crescente, corpo de trabalhos sobre o suicídio nas Américas, onde os encontros coloniais levantam questões difíceis sobre esse tema complexo e problemático em qualquer circunstância. The power to die: Slavery and suicide in British North America, de Snyder, e To die in Cuba: Suicide and Society, de Louis A. Pérez Jr., são os dois únicos livros sobre suicídio e raça nas Américas. ${ }^{11}$ Richard Bell, Michael Gómez, William Piersen, Zeb Tortorici, e outros, têm feito intervenções similares cruciais. ${ }^{12}$ Todos concordariam

9 WRIGHT, David; John WEAVER, John. Introduction. In: WRIGHT, David; John WEAVER, John (org.). Histories of suicide: International perspectives on self-destruction in the modern world. Toronto: University of Toronto Press, 2009. p. 3-18. p. 4. Ver também: MINOIS, op. cit.; WATT, Jeffrey R. (org.). From sin to insanity: Suicide in early modern Europe. Ithaca, NY: Cornell University Press, 2004.

10 MORRISSEY, Susan K. Drinking to death: Suicide, vodka and religious burial in Russia. Past and Present, n. 186, p. 117-146, Feb. 2005, p. 145. Craig M. Koslofsky também complexificou a escola secularizada; KOSLOFSKY, Craig. Controlling the body of the suicide in Saxony. In: WATT, op. cit., p. 48-63.

11 SNYDER, Terri L. The power to die: Slavery and suicide in British North America. Chicago: University of Chicago Press, 2015; PÉREZ JR., Louis A. To die in Cuba: Suicide and society. Chapel Hill, N.C.: The University of North Carolina Press, 2005.

12 BELL, Richard. We shall be no more: suicide and self-government in the newly United States. Cambridge, Mass.: Harvard University Press, 2012. GOMEZ, Michael A. A quality of anguish: The Igbo response to enslavement in North America. In: LOVEJOY, Paul E.; TROTMAN, David V. (org.). Trans-Atlantic dimensions of ethnicity in the African diaspora. London: New York: Continuum, 2003. p. 82-95; PIERSEN, William D. White cannibals, black martyrs: fear, depression, and religious faith as causes of suicide among new slaves. Journal of Negro History, v. 62, n. 2, p. 147-159, 1977; TORTORICI, Zeb. Reading the (dead) body: Histories of suicide in New Spain. In: 
que muitas questões permanecem. Embora tenhamos uma compreensão básica do escopo da mortalidade durante a invasão europeia do Atlântico, e sob a escravidão, não há um entendimento quantitativo ou coeso do papel do suicídio no massacre. Quantas vezes escravos e indígenas se mataram? Quando o fizeram, foi um ato de resistência? Ainda é possível responder a essas perguntas? A recente pesquisa acadêmica no Brasil fornece os melhores dados quantitativos sobre o suicídio de escravos, mas consiste principalmente em estudos locais e regionais; e, como qualquer trabalho sobre suicídio, é limitado em sua capacidade de determinar a intenção. ${ }^{13}$ Os marinheiros do Atlântico muitas vezes se perguntavam se os escravos africanos que saltavam de navios o faziam para se matar, ou por uma necessidade desesperada de água. ${ }^{14}$ Certamente muitos escravos que pularam acalentavam ideias de morte e de fuga.

O problema é agravado ainda mais pelos significados culturalmente específicos do suicídio. Fora do Japão, pilotos kamikazes são equiparados a suicídio, mas, como explica Emiko Ohnuki-Tierney, "nem os próprios pilotos nem o público japonês consideraram seus atos como atos de suicídio". ${ }^{15}$ No sul dos Estados Unidos e no Caribe, o que os proprietários de escravos chamam de suicídio parece ter sido entendido por muitos escravos e seus descendentes como o ato libertador de "voltar para casa", um exemplo claro de como os significados da autodestruição são frequentemente locais, controversos e distintos daqueles impostos de fora. ${ }^{16}$

Entretanto, os estudiosos geralmente consideram o significado de tirar a própria vida, especialmente quando se trata de escravos e outros grupos "subalternos", quase sempre como um ato de resistência. Há, certamente, muitas evidências a sugerir tal leitura. Um dos exemplos mais famosos e pungentes ocorreu em 1803,

CHAPARRO, Martina Will de; ACHIM, Miruna. (org.), Death and dying in colonial Spanish America. Tucson, Arizona: University of Arizona Press, 2011. p. 53-77.

13 Ver, entre outros: CANÁRIO, Ezequiel David do Amaral. É mais uma scena da escravidão: suicídios de escravos na cidade do Recife, 1850-1888. 2011. Dissertação (Mestrado em História) - Programa de Pós Graduação em História, Universidade Federal de Pernambuco, Recife, 2011;. FERREIRA, Jackson. Por hoje se acaba a lida: suicídio escravo na Bahia (1850-1888). Afro-Ásia, n. 31, p. 197234, 2004; LOPES, Fábio Henrique. O suicídio como perigo social e urbano: as teses médicas brasileiras. Revista do Instituto Histórico e Geográfico Brasileiro, v. 169, n. 438, p. 91-112, 2008. OLIVEIRA, Saulo Veiga. O suicídio de escravos em Campinas e na província de São Paulo (1870-1888). 2007. Dissertação (Mestrado) - Universidade Estadual de Campinas, Campinas, 2007. VENÂNCIO, Renato Pinto. A última fuga: suicídio de escravos no Rio de Janeiro (1870-1888). Revista de História, n. 1, p. 80-89, 1990.

14 Ver, por exemplo: CONRAD, Robert Edgar. Children of god's fire: A documentary history of black slavery in Brazil (1983). Princeton: Princeton University Press, 1983. Reeditado pela University Park, Penn., 1994. p. 34.

15 OHNUKI-TIERNEY, Emiko. Kamikaze, cherry blossoms, and nationalisms: The militarization of aesthetics in Japanese history. Chicago: University of Chicago Press,, 2002. p. 20.

16 Sobre "voar para casa", ver, entre outros: GOMEZ, Michael A. Exchanging our country marks: The transformation of African identities in the colonial and antebellum south. Chapel Hill, N.C.: The University of North Carolina Press, 1998. p. 117-118. SNYDER, op. cit., 2015, p. 57-58 e 157-166. 
quando um grupo de escravos igbo pereceu ao largo da costa da Geórgia, no que é lembrado como um suicídio coordenado e coletivo, realizado em resposta aos horrores da travessia atlântica e como um meio de fazer a jornada espiritual de volta para casa através do mesmo oceano. ${ }^{17}$ Mas se o suicídio do escravo pode muitas vezes ser entendido como resistência, também há motivo para cautela. Snyder convida os historiadores a ir além do "modelo de resistência" e explorar também uma "ecologia" maior de significados e motivos. ${ }^{18}$ Tortorici pergunta: "Os historiadores têm mais probabilidade de enquadrar o ato suicida de uma pessoa africana ou indígena como resistência ao colonialismo, enquanto veem ações semelhantes de um indivíduo europeu, sacerdote ou rico como enraizado nas particularidades imediatas de sua própria vida?"19 Nesse espírito, podemos fazer outro conjunto de perguntas: Se, como Tortorici sugere, os historiadores, hoje, tendem a conceituar suicídios africanos, nativos e outros não brancos de maneira semelhante, isso sempre foi assim? Como gerações anteriores de estudiosos e outros observadores entenderam a relação entre raça e suicídio na América?

Talvez, ao abordar essas questões, possamos entender melhor como as ideias sobre o suicídio ajudaram a criar e enfatizar a diferença racial (muitas vezes traduzida em termos de gênero e sexo), dentro e além dos padrões das fronteiras nacionais, regionais e linguísticas. Apesar do potencial do suicídio para condensar, em um ato único e devastador, a violência e a tragédia insondáveis produzidas pela escravidão e pelo colonialismo, ele também teve uma função simbólica bem diferente. Com a mesma frequência, o suicídio ajudou a determinar quais grupos se tornavam parte das mitologias raciais nacionais, os termos sob os quais eram admitidos e quem era excluído. As ideias sobre raça moldaram opiniões sobre suicídio e vice-versa. Esse processo mutuamente constitutivo envolveu povos negros, brancos e nativos - o "triângulo" de grupos que estudiosos e leigos colocam com tanta frequência no coração das sociedades latino-americanas - e outros, também, incluindo os trabalhadores asiáticos - coolies - que chegaram quando a escravidão terminou no século $\mathrm{XIX}{ }^{20}$

A economia ajudou a moldar as discussões sobre a autodestruição. Embora estudiosos europeus costumem sugerir que o capitalismo transformou as ideias

17 SNYDER, Terri L. Suicide, slavery, and memory in North America. Journal of American History, v. 97, n. 1, p. 39-62. 2010. p. 39. The deaths at Igbo Landing (também Ibo, Ebo ou Ebos Landing) está representado na ilustração encontrada no começo deste artigo.

18 Ibidem, p. 42.

19 TORTORICI, op. cit., p. 61.

20 LESSER, Jeffrey. Negotiating national identity: immigrants, minorities, and the struggle for ethnicity in Brazil. Durham, N.C.: Duke University Press Books, 1999. p. 11. 
sobre o suicídio, criando novas modernidades e novas tensões para os trabalhadores, houve pouco envolvimento com o fato brutal, amplamente reconhecido pelos historiadores da escravidão (embora quase sempre de passagem), de que senhores e traficantes entendiam o suicídio como um obstáculo à produção e, de fato, até muito mais: um ataque direto ao investimento de capital e aos ganhos futuros. Para qualquer sociedade que dependesse de trabalho forçado, o suicídio não era apenas uma questão moral, religiosa ou médico-legal, mas também racial e econômica. ${ }^{21}$ Embora a preguiça ou a indolência pudessem atrair a ira de um senhor e afetar a produção de plantações, o suicídio - independentemente da intenção oculta - era um ataque dramático à riqueza branca.

O suicídio apresenta questões metodológicas delicadas e escolhas difíceis. Junto com a tarefa muitas vezes impossível de discernir intenções, os estudiosos enfrentam um desafio familiar junto a qualquer estudioso da escravidão, descrito num recente fórum da revista Social Text. a tensão entre perseguir o objetivo de "recuperar os vestígios arquivísticos da vida negra" e aceitar "o arquivo como um local de silêncio irrevogável que reproduz as hierarquias raciais intrínsecas à sua construção". ${ }^{22}$ Além disso, escreve Lisa Lowe, qualquer tentativa de recuperar vozes perdidas da escravidão e a travessia atlântica devem ser entendidas "dentro dos limites de um arquivo que autoriza o conhecimento [...] nos termos de interesses particulares - de proprietários de escravos e cidadãos, mas não de escravizados". ${ }^{23}$ Nas Américas, nosso conhecimento do suicídio foi irrevogavelmente moldado pelos interesses e visões particulares das elites brancas, que procuraram entender e controlar a autodestruição em seus próprios termos e, no processo, negar a humanidade aos não brancos. Pouca atenção é dada a esse fato ou às suas implicações sobre como entendemos "recuperação" e "silêncio".

Pérez faz a fascinante observação de que, na Cuba do século XIX, é muito mais fácil rastrear os suicídios de escravos e trabalhadores contratados do que de brancos ou pessoas de cor, livres, devido, em parte, à capacidade das famílias ricas em esconder e evitar os estigmas ligados a ele. ${ }^{24} \mathrm{~A}$ disparidade também certamente vem do hábito dos senhores de registrar (e reclamar) as "perdas de mão-de-obra" e da patologização do suicídio não branco por observadores coloniais. O registro

\footnotetext{
21 Snyder, cujo livro conclui com o fim da escravidão, apresenta a mais extensa discussão sobre a economia do suicídio. Exemplos representativos da relação causal entre o capitalismo e o suicídio moderno na Europa são encontrados em MINOIS, op. cit, p. 81 e 185.

22 HELTON, Laura; LEROY, Justin; MISHLER, Max A.; SEELEY, Samantha; SWEENEY, Shauna. The question of recovery: An introduction. Social Text, v. 33, n. 4, p. 1-18, 2015. p. 2.

23 LOWE, Lisa. History hesitant. Social Text, v. 33, n. 4, p. 85-107, 2015. p. 85.

24 PÉREZ JR., op. cit, p. 132 e 135.
} 
histórico, então, não apenas silencia atores não brancos e nos convida a recuperar suas histórias; também exige um exame atento de como as mortes não brancas foram dissecadas e escrutinadas, enquanto outros suicídios foram ocultados e não identificados. Em outras palavras, concentrar-se apenas na "recuperação" e no "silêncio" é cair nas armadilhas discutidas por Tortorici e perder outros aspectos importantes da história do suicídio.

Em contraste com os Estados Unidos, com sua rica história de narrativas de escravos, a América Latina não preservou quase nenhum relato escrito de escravos. Embora o futuro trabalho arquivístico prometa fornecer mais perspectivas de atores que não eram a elite, muito do que sabemos sobre a história do suicídio nas Américas vem daqueles que falaram e escreveram a partir de lugares de poder. Durante a era colonial, tanto escritores proeminentes e influentes, quanto atores históricos menos conhecidos, registraram seus pensamentos em livros, diários e, cada vez mais, durante os séculos XIX e XX, em jornais e revistas acadêmicas. Quando rastreadas no tempo e no espaço, essas fontes sugerem que a raça é atrelada ao suicídio por indivíduos que operam com fins únicos e raramente de maneira bem coordenada, ou dentro de um conjunto de instituições ou gêneros de escrita facilmente circunscrito. Embora textos, como tratados médicos, possam ser explicitamente relacionados ao suicídio, há discussões sobre autodestruição em trabalhos dedicados a outros tópicos - conquista, viagens, identidade nacional - que contêm referências menores e passageiras, mas reveladoras sobre ideias amplamente aceitas e internalizadas. ${ }^{25}$

Embora um estudo mais restrito radicado num único local, em cronologia mais curta, ou um arquivo ou fonte mais obviamente unificado possa facilitar a recuperação de mais vozes de suicidas, é ao mesmo tempo limitado no que ele pode nos dizer especificamente sobre as relações entre as Américas "afro" e "indígena", entre a escravidão e suas consequências, e entre ideias coloniais e conhecimento contemporâneo. Embora essas escolhas não permitam recuperar as tantas vozes daqueles que morreram por suas próprias mãos, elas de fato facilitam uma ampla

25 Num artigo provocativo recentemente publicado, Lara Putnam argumenta que os historiadores precisam ser mais francos sobre seus hábitos de buscas digitais. Como ela e outros mostraram, a proliferação de textos pesquisáveis favorece certas fontes e atores históricos em detrimento de outros e cria "pontos cegos sistemáticos". Tendo gerado minhas principais questões e ideias por meio de pesquisa em arquivo e leituras de fontes primárias e secundárias, ao longo do tempo eu complementava e expandia esses trabalhos iniciais de "relance" através de repositórios digitais pesquisáveis, para encontrar textos e exemplos que eu não teria como descobrir de outra maneira e, em seguida, fazia o possível para contextualizar essas fontes "terciárias". No entanto, a disponibilidade de material substancial on-line que poderia abordar minhas preocupações aqui é limitada e, como Putnam sugere, há algumas perguntas e histórias que não podem ser abordadas adequadamente apenas por meio da digitalização. PUTNAM, Lara. The transnational and the textsearchable: digitized sources and the shadows they cast. American Historical Review, v. 121, n. 2, p. 377-402, Apr. 2016. p. 379 e 383. 
visão geográfica e temporal de como agentes poderosos definiram o suicídio e o associaram à raça e ao trabalho forçado nas Américas. Suas palavras e ideias contam uma história importante sobre como o suicídio e a escravidão ajudaram a definir quem era considerado totalmente humano, até muito depois da abolição.

As lacunas epistemológicas em nossa compreensão da história do suicídio são totalmente visíveis quando entendemos a produção acadêmica dos séculos $X X$ e XXI como um arquivo moldado por séculos de colonialismo. Escrevendo em 1937, cinco décadas após a abolição e 35 anos depois da proclamação da Independência, um autor cubano acreditou nas palavras de um agricultor colonial e concluiu que a religião nativa "não apenas não proibia o suicídio, como talvez ... até o encorajasse". ${ }^{26}$ Nesse caso, a genealogia da ideia é clara: um observador do século XX encontra provas de sua afirmação num documento escrito por um proprietário de escravos, cujas ideias ele aceita sem questionar. Em outros casos, origens precisas não são tão evidentes. Em 1993, Doris Sommer escreveu: "Os índios [brasileiros] frequentemente preferiam se retirar para a selva ou cometer suicídio do que permanecer confinados à vida estável das missões [jesuíticas]". ${ }^{27}$ Nenhuma citação acompanha essa afirmação, que, sendo ou não confiável, é um bom exemplo da extrapolação que frequentemente acompanha as afirmações acadêmicas sobre o suicídio. ${ }^{28}$ Como esses exemplos sugerem, o arquivo do suicídio colonial das Américas não existe de maneira ordenada, nem suas origens são sempre fáceis de rastrear. Essa obscuridade é importante: algumas ideias racializadas sobre o suicídio tornaram-se tão naturalizadas que suas origens parecem vir de qualquer lugar e de lugar nenhum. Hoje, algumas suposições seminais permanecem intactas (por exemplo, a ideia de que os povos nativos "preferem" o suicídio), enquanto outras moldam o conhecimento de maneira menos direta, como o "modelo de resistência", um reencontro significativo, mas também limitado a séculos de apagamento e patologização.

O apagamento e a patologização marcaram discussões sobre o suicídio durante a era colonial e o século XIX. As referências ao suicídio africano são muito mais numerosas do que ao nativo, embora o Caribe forneça uma exceção macabra.

26 ROSSEL, Rafael Azcárate. Historia de los indios de Cuba. La Habana: Editorial Tropico, 1937. p. 216.

27 SOMMER, Doris, Foundational fictions: The national romances of Latin America. Berkeley, Calif.: University of California Press, 1993. p. 139.

28 Beatriz Reyes-Foster e Rachael Kangas chamam atenção para um problema similar no México, onde, elas argumentam, os acadêmicos do século XX interpretaram mal os autores coloniais espanhóis, que deturpavam, eles mesmos, práticas e códices maias, confundindo assim as execuções maias por enforcamento, como suicídio e inventando efetivamente uma falsa tradição de suicídio "indígena". REYES-FOSTER, Beatriz; KANGAS, Rachael. Unraveling x Tab: Revisiting the 'suicide goddess' in maya archaeology. Ethnohistory, v. 63, n. 1, p. 1-27, 2016. 
Lá, os indígenas pereceram notavelmente depressa, até mesmo para os terríveis padrões de conquista. Essa realidade brutal facilitou a especulação imaginativa que tanto foi, de longe, projetada para a América Latina, quanto gerada a partir de dentro. O historiador britânico (e colonialista e supremacista branco) James Froude escreveu em 1868 que as ilhas caribenhas inteiras "ficaram literalmente desoladas pelo suicídio". ${ }^{29}$ Juan Pérez de la Riva, demógrafo cubano do século XX, estimou que até um terço dos habitantes pré-colombianos da ilha se mataram depois da chegada dos europeus. ${ }^{30}$ Esse número, impossível de ser verificado, é um bom exemplo de como os observadores costumam tornar os aspectos intrinsecamente ilusórios do suicídio tão concretos e prontamente reconhecíveis. Nem Froude, nem Riva, fornecem muitas pistas sobre fontes ou evidências, ao contrário, simplesmente consideram o suicídio uma explicação óbvia para a dizimação colonial.

Dinâmicas semelhantes marcam representações mais românticas. Uma narrativa cubana fundacional descreve homens e mulheres, no vale de Yumur, que fugiam dos espanhóis até chegarem à beira de um penhasco de onde, segundo o conto, saltavam para a morte. ${ }^{31}$ Ao contrário das de Froude e dos demógrafos e de Cuba, esta história atribui certo valor romântico a homens e mulheres nativos. Mas aqui, novamente, suas origens não são claras. Como a conclusão não conferida de Sommer, sobre a preferência dos índios brasileiros pela morte, a história tornou-se parte do conhecimento histórico aceito.

Quer seja melancólica ou romântica, a maioria dos relatos coloniais de suicídio indígena enfatiza a vitimização. Talvez o exemplo mais conhecido venha de Bartolomeu de las Casas, que usou o suicídio para criticar a violência colonial espanhola e demonstrar a necessidade de proteger os nativos "desamparados". 32 Girolamo Benzoni, comerciante italiano que viajou pelas Américas e, como Las Casas, criticou o empreendimento espanhol ali, escreveu que "com suspiros e lágrimas", os nativos "ansiavam pela morte". Mulheres, cujos maridos cometeram suicídio, ele continuou, abortaram a gravidez e seguiram seus maridos matando-se. ${ }^{33}$

29 FROUDE, James Anthony. Short studies on great subjects. New York: Charles Scribner's Sons, 1868. p. 376. Sobre o "colonizador heróico", de Froude, ver: BEHM, Amanda. Settler historicism and anticolonial rebuttal in the British world, 1880-1920. Journal of World History, v. 26, n. 4. p. 785813, 2015. p. 802. nota 57.

30 PÉREZ DE LA RIVA, Juan. Desaparición de la población indígena cubana. Universidad de La Habana, n. 196-197, p. 61-84, 1972. p. 80.

31 PÉREZ JR., op. cit., p. 5.

32 CASAS, Bartolomé de las. Historia de las Indias. Madrid: Miguel Ginesta, 1875. 3 v., v. 2, p. 364. CASAS, Bartolomé de las. A short account of the destruction of the Indies. London: Penguin Group: 1992. p. 29-30. Tradução de Nigel Griffin. ALCHON, Suzanne Austin. A pest in the land: New world epidemics in a global perspective. Albuquerque, N. Mex.: University of New Mexico Press, 2003. p. 113. PÉREZ JR., op. cit., p. 3.

33 Citado e traduzido por: PÉREZ JR, op. cit, p. 4-5. 
O clérigo jesuíta Antonio Ruiz de Montoya empregou tropos semelhantes, escrevendo sobre mulheres guaranis da América do Sul: "Com a morte de seus maridos, as esposas gritando se lançam de uma altura de três jardas, às vezes sofrendo morte ou incapacitando-se no impacto". ${ }^{34}$ Nem todos os observadores associaram o suicídio nativo às mulheres, mas muitos sugeriram que ele tinha conotações de feminilidade, chamando os indígenas de fracos e frágeis. Um espanhol no México escreveu que os povos indígenas eram "fatalistas" e se permitiam "morrer como bestas". Um clérigo alemão na América do Norte opinou: "Os índios morrem tão facilmente que o mero olhar e o cheiro de um espanhol faz com que eles morram". ${ }^{35}$ Um jesuíta escreveu sobre os brasileiros nativos: "Qualquer ataque de disenteria os mata; e por qualquer pequeno aborrecimento eles começam a comer terra ou sal e morrem". ${ }^{36}$

As discussões sobre o suicídio nativo circularam pelo Atlântico e por toda a América, impulsionadas por clérigos e outros que apoiavam empreendimentos coloniais e missionários, e também por aqueles que, como Las Casas, tinham relações mais ambíguas com eles. El Inca Garcilaso de la Vega, filho de um conquistador espanhol e de uma nobre inca, narrou a expansão colonial espanhola, ao mesmo tempo em que afirmava a supremacia indígena. Em 1605, ele escreveu que "quase todos" os povos nativos de Cuba se enforcaram após a chegada dos espanhóis. Isso, explicou Garcilaso, levou à importação em massa de escravos "negros", uma afirmação que reflete como, desde muito cedo, o suicídio se tornou parte de uma matriz racializada que distinguia os africanos dos nativos e os lançava como incapazes de serem escravos e realizar o trabalho brutal, viril, que alimentou o colonialismo. ${ }^{37}$

Se os observadores coloniais descreveram a autodestruição nativa como um sinal de fraqueza, eles entenderam o suicídio escravo em termos diferentes. Por um lado, o assunto os consumiu mais do que àqueles que escreveram sobre a América nativa. Senhores de escravos, comerciantes, cirurgiões, capitães de navios e

34 RUIZ DE MONTOYA, Antonio. The spiritual conquest accomplished by the religious of the Society of Jesus in the provinces of Paraguay, Parana, Uruguay, and Tape. St. Louis, MO: Institute of Jesuit Sources, 1993. p. 50. Traduzido por C. J. McNaspy, John P. Leonard e Martin E. Palmer.

35 Ambos citados e traduzidos por: ALCHON, op. cit., p. 113.

36 Citado e traduzido por: HEMMING, John. Red gold: The conquest of the Brazilian indians. London: Macmillan, 1978. p. 338. Sobre o mito de comer terra entre os escravos africanos, ver: HOGARTH, Rana Asali. Comparing anatomies, constructing races: Medicine and slavery in the Atlantic world, 1787-1838. 2012. Tese (Doutorado) - Yale University, 2012. p. 97-108.

37 VEGA, Garcilaso de la. La Florida del inca, Hernando de Soto, gobernador, y capitan general del reino de la Florida: y de otros heroicos caballeros, españoles e índios. 2. ed. GONZALEZ DE BARCIA CARBALLIDO Y ZUÑIGA, Andrés. Madrid: [s.n.], 1723, p. 16-17. 
governantes, comentavam regularmente sobre os escravos que se matavam. ${ }^{38} \mathrm{Em}$ 1791, a Câmara dos Comuns britânica realizou uma investigação e uma audiência dedicada inteiramente ao tema. ${ }^{39}$ Os europeus e euro-americanos não só falaram mais sobre o suicídio africano do que o nativo, mas também usaram termos diferentes para discutir os dois. A autodestruição dos escravos não era um sinal de fragilidade, mas um marcador de agressão patológica e um obstáculo à produção: em contraste com os nativos que se renderam à morte, os africanos a apreenderam e, no processo, diminuíram a riqueza de seus senhores.

À medida que os observadores coloniais e do século XIX atravessavam a fantasia e o medo raciais, a predisposição suicida tornou-se uma explicação para a perda monetária. Um viajante no Brasil do século XIX observou: "Os suicídios ocorrem continuamente e os proprietários se surpreendem. Na altamente anímica Minas, tanto homens quanto mulheres são dados à autodestruição. Em vez de suportar a vida nos termos que Ihes são oferecidos, muitos acabam com ela. Então, aqueles que os compraram rangeram e xingaram, lançaram imprecações sobre seus espíritos fujões e execraram os santos que os deixaram ir". O grau de trituração dos dentes dependia da própria posição do senhor: "Pessoas ricas que perdem um escravo por suicídio ou por fuga mal sentem a perda, mas para muitas famílias a perda é ruinosa". ${ }^{40}$

Em contraste com as implicações "femininas" do suicídio nativo, a capacidade dos escravos de causar pena financeira alimentou uma compreensão do suicídio africano como um "sintoma masculino", uma marca com raízes profundas e durabilidade notável. Esta marca inspirou ideias sobre o relacionamento dos africanos com a morte em geral e sobre atos mais específicos e "agressivos" de autoimolação - cortando a própria garganta ou saltando do convés de um navio negreiro para o mar. No início do século XVIII, o traficante de escravos francês Jean Barbot escreveu sobre a abordagem estoica dos africanos à mortalidade e como, "sem cuidado, mas com firmeza", eles "correriam para as circunstâncias mais perigosas", com pouca preocupação do risco de morrer. ${ }^{41}$ Quase um século e meio depois, o abolicionista britânico Wilson Armistead observou "um espírito de

38 As menções ao suicídio de escravos eram tão ubíquas em Cuba que Robert L. Paquette escreve: "Raro é o diário ou livro de contas de plantation cubano que não faz menção a eles". PAQUETTE, Robert L. Sugar is made with blood: the conspiracy of la escalera and the conflict between empires over slavery in Cuba. Middletown, Conn.: Wesleyan University Press, 1988. p. 71.

39 SNYDER, op. cit.

40 EWBANK, Thomas. Life in Brazil; or a journal of a visit to the Land of the cocoa and the palm. Nova York: Harper \& Brothers, 1856. p. 440.

41 HAIR, Paul; JONES, Adam; LAW, Robin (ed.). Barbot on Guinea: The writings of Jean Barbot on West Africa, 1678-1712. London: Ashgate Pub Co, 1992. v. 2, p. 639. SNYDER, op. cit., p. 24, 67. 
independência inabalável" que "levava [os negros] a cometer suicídio". ${ }^{42}$ Entre essas polaridades históricas, inúmeros senhores de engenhos e capitães de navios expressavam opiniões semelhantes, reclamando abertamente - e criando estratégias ativas para combater os africanos truculentos que tiravam suas próprias vidas. Recentemente, em 2010, um historiador demográfico ressuscitou o rótulo de "sintoma masculino", a partir de poucas evidências empíricas. ${ }^{43}$

Muitos comerciantes e senhores de escravos acreditavam que a propensão dos africanos ao suicídio variava de acordo com a região e o grupo. A reputação dos escravos igbo da baía de Biafra, como especialmente propensos ao suicídio, se estendia através do Caribe e dos Estados Unidos, onde os comerciantes e senhores evitavam ativamente sua importação. ${ }^{44} \mathrm{Em}$ outros lugares, os observadores atribuíram o pathos suicida a outros grupos. Esses rótulos eram flexíveis, para dizer o mínimo. Os escravos fantes, por exemplo, eram alternadamente descritos como dispostos e avessos ao suicídio. ${ }^{45}$

Os europeus e euro-americanos usaram o suicídio não apenas para diferenciar e rotular grupos africanos, mas também para distinguir entre brancos e pretos. No final do século XVIII, um agente da Inquisição em Cartagena sugeriu que os africanos eram responsáveis por introduzir a prática "inumana e execrável" do suicídio na colônia americana e fazê-la se espalhar entre os não negros. ${ }^{46}$

Algumas décadas mais tarde, o reverendo irlandês Robert Walsh escreveu que os escravos no Brasil "...parecem ter um aguçado senso de servidão e repelir amargamente seu destino, como qualquer homem branco no mesmo estado na África".

Mas, continuou ele, “...nunca ouvi dizer que o suicídio fosse comum entre os infelizes europeus, detidos em escravidão na costa berbere; é a prática diária no Brasil". ${ }^{47}$ As observações de Walsh refletem uma compreensão do suicídio como um sinal de depreciação: onde os escravos brancos sofriam com o destino que lhes era

42 ARMISTEAD, Wilson. A tribute for the negro: Being a vindication of the moral, intellectual, and religious capabilities of the coloured portion of mankind; with particular reference to the African race. Manchester: William Irwin, 1848. p. 162.

43 MALVIDO, Elsa. El suicidio entre los esclavos negros en el Caribe en general y en el franc'és en particular: Una manera de evasión considerada enfermedad, siglos XVII y XVIII. Trace, n. 58, p. 113124, 2010.

44 GOMEZ, 1998, op. cit., p. 116-120, 127-128, 131. GOMEZ, 2003, op. cit.

45 AGUIRRE BELTRÁN, Gonzalo. La población negra de México: Estudio etnohistorico. México, DF: Fondo de Cultura Económica, 1972. p. 186. PIERSEN, op. cit., p. 158, notas 59-60.

46 Citado e traduzido por: GERMETEN, Nicole von. Archival narratives of clerical sodomy and suicide from eighteenth-century Cartagena. In: TORTORICI, Zeb. (org.). Sexuality and the unnatural in colonial Latin America. Berkeley, Calif. University of California Press, 2016. p. 23-42. p. 35.

47 WALSH, R. Notices of Brazil in 1828 and 1829. Boston: [s.n.], 1831. v. 2, p. 344. 
entregue, os africanos no Brasil não tinham a virtude e a disciplina para permanecer vivos, apesar das dificuldades.

Os tratados médicos faziam distinções semelhantes, tratando a melancolia, por exemplo, como uma doença que prejudicava a produtividade dos escravos e os levava à morte. Traduzir as ideias continentais sobre a melancolia e a nostalgia no contexto da escravidão ibérica no Atlântico não era uma tarefa simples.

Na Europa do século XVIII, a nostalgia era considerada "uma forma patológica de amor patriótico" que afetava principalmente aqueles que tinham meios para viajar e ansiavam pelo lar, quando estavam longe ou que sofriam "aflições do coração". ${ }^{48}$ Do outro lado do oceano, diferentes termos foram aplicados. Os escravos negros sofriam com a melancolia e ansiavam pela morte não porque eram refinados, mas porque sua primeira exposição à "civilização" era chocante e desorientadora. O tratado de um cirurgião espanhol do final do século XVIII atribuiu aos escravos a maturidade emocional necessária para compreender a tragédia de sua condição, ao mesmo tempo em que os ridicularizava como sensíveis, invejosos e grosseiros. ${ }^{49}$ Os traficantes e senhores de escravos e os médicos do mundo português gastaram muito tempo e energia discutindo o banzo, doença que eles entendiam ser uma forma potencialmente fatal de nostalgia que afligia e frequentemente resultava na morte de escravos. ${ }^{50}$

Os traficantes muitas vezes tratavam o suicídio como qualquer outra forma de morte que diminuísse seu estoque de força de trabalho, descartando na mata "os corpos de cativos que se matavam no caminho para o porto, juntamente com aqueles que pereciam de outras maneiras". ${ }^{51}$ Outros fizeram grandes esforços para evitar a morte autoinfligida. Traficantes e proprietários quebraram mandíbulas de escravos para empurrar comida e água abaixo de suas gargantas, mutilaram os corpos de escravos que se mataram e criaram outras formas horríveis de "dissuasão" ${ }^{52}$ Profundamente conscientes de seu próprio valor, alguns escravos brandiam o suicídio como uma ameaça. Em Lima, em 1819, Ana María Murga ameaçou se matar para garantir sua transferência para um senhor menos opressivo: "Se ... Vossa

48 LÓPEZ DENIS, Adrián. Melancholia, slavery, and racial pathology in eighteenth-century Cuba. Science in Context, v. 18, n. 2, p. 179-199, 2005. p. 182.MACDONALD, Michael; MURPHY, Terence R. Sleepless souls: Suicide in early modern England. Oxford: Oxford University Press, 1990. p. 292.

49 Ibidem, p. 183, 185, 186.

50 Por exemplo: ODA, Ana Maria Galdini Raimundo. Escravidão e nostalgia no Brasil: o banzo. Revista Latinoamericana de Psicopatologia Fundamental, v. 11, n. 4, 2008. p. 735-761. VENÂNCIO, Renato Pinto; LANNA, Maria Célia da S. Banzo: desnutri şão e morte do escravo. Ciência Hoje, v. 21, n. 126, p. 42-47, 1997.

51 BROWN, Vincent. The reaper's garden: Death and power in the world of Atlantic slavery. Cambridge, Mass.: Harvard University Press, 2007. p. 34.

52 BROWN, Vincent. Spiritual terror and sacred authority in Jamaican slave society. Slavery and Abolition, v. 24, n. 1, p. 24-53, 2003. p. 26-27. PÉREZ JR., op. cit., p. 37-41, 58-60. 
Excelência ordenar que eu retorne ao seu serviço", declarou no tribunal, "estou determinada a cometer suicídio, e ele [seu atual senhor] perderá seu dinheiro assim como eu perco a vida". ${ }^{53}$ Embora ela não tenha tido sucesso em seu apelo legal, as ações de Murga não deixam dúvidas sobre os termos com que muitos escravos e senhores entendiam a autodestruição. ${ }^{54}$

As implicações econômicas do suicídio escravo foram sentidas em todo o Atlântico. Os estudiosos haviam observado, há muito tempo, que as pessoas que viviam na Europa tratavam a escravidão como uma metáfora, enquanto obstinadamente ignoravam as realidades de suas vidas. ${ }^{55}$ Aqueles que traficavam diretamente o trabalho humano se envolveram em uma forma diferente de deslocamento conceitual. Se a escravidão era mais real nas linhas de frente da expansão colonial, isso não tornava os escravos mais humanos. Tampouco a distância geográfica habituou os que viviam na Europa ao impacto financeiro ou legal da autodestruição de escravos. Investidores britânicos regateavam se as mortes por suicídio deveriam ser indenizadas da mesma maneira que outras "perdas" . ${ }^{56}$ Mesmo para os indivíduos que viviam na Europa, separados da escravidão colonial por um oceano, o suicídio levou a raça e o capital a um nó, cuja tensão revelava a potencial fragilidade das fortunas coloniais que dependiam de negar aos escravos a capacidade quintessencialmente humana de se matar.

O fato de os traficantes de escravos descartarem os corpos das vítimas de suicídio, assim como dos que eram dizimados por doenças, reflete um grau de semelhança entre o suicídio e outras causas de fatalidade dos escravos. O mesmo pode ser dito da América nativa, onde os colonizadores viam o suicídio como um exemplo de inferioridade e fraqueza indígenas. E, no entanto, o suicídio também funcionava de maneira diferente. Os senhores teriam poucas razões para desmembrar cadáveres ou conceber outros esquemas elaborados para evitar que os escravos se matassem se "o poder de morrer", como Snyder coloca, não representasse uma ameaça singular aos interesses financeiros dos senhores e dos projetos coloniais mais amplos. ${ }^{57}$

\footnotetext{
53 Citado e traduzido por: HÜNEFELDT, Christine. Paying the priec of freedom: Family and labor among lima's slaves, 1800-1854. Berkeley, Calif.: University of California Press, 1994. p. 182.

54 Flores Galindo sugere que estas ameaças eram comuns. FLORES GALINDO, Alberto. Aristocracia y plebe: Lima, 1760-1830: estructura de clases y sociedad colonial. Lima: Mosca Azul Editores, 1984. p. 126.

55 SNYDER, op. cit., p. 20.

56 Ibidem.

57 Ibidem.
} 
Embora suas relações com a escravidão e o colonialismo fossem diferentes, as vozes mais altas e mais bem preservadas descreviam o suicídio como um marcador da diferença racial. Os escravos brancos resistiam à morte; os negros a perseguiam. Os africanos saltaram de barcos, cortaram suas gargantas e assumiram a mortalidade; os nativos "fatalistas" resignavam-se à morte, deixando-se passivamente arrastar e serem levados embora. Certamente, as fronteiras poderiam se confundir, apoiadas como eram nas bases perpetuamente cambiantes da raça. Mas a afinidade não impedia a separação e quando os observadores europeus e euro-americanos falavam em suicídio eles falavam com mais frequência das diferenças das quais dependiam seus projetos coloniais.

Esses projetos, em algum momento, entraram em conflito com os movimentos anticoloniais. A maior parte da região conquistou a independência durante o início do século XIX, embora Cuba e Porto Rico permanecessem sob controle espanhol até a virada do século XX. O Brasil se tornou independente em 1822, mas permaneceu monárquico e escravista até o final da década de 1880. Em todo o hemisfério, a independência e a abolição se entrelaçaram graças, em parte, à forte dependência de soldados não brancos para derrotar as forças coloniais.

Escrevendo em 1806, no momento em que esses processos estavam em convulsão, o intelectual andino Hipolito Unanue afirmou que o suicídio era raro na Lima "civilizada", mas comum entre os indígenas rurais, ignorantes da "proteção benigna" do cristianismo. ${ }^{58}$ Unanue antecipou algumas das famosas observações de Alexander von Humboldt sobre a história natural da América, argumentando que o Peru era, como Mark Thurner expôs, "mais universal do que qualquer terra do mundo" ${ }^{59}$ Essa universalidade, baseada na diversidade natural e racial, não implicava, naturalmente, igualdade interna, um ponto deixado claro nas reflexões da Unanue sobre o suicídio, que apagou de uma só vez histórias como as de Ana Maria Murga e reforçou uma distinção geográfica e racialmente contingente entre civilizado e selvagem.

Nas Américas, discursos de fragilidade nativa se fundiram facilmente com narrativas de desaparecimento. Os autores dos "romances nacionais" da América Latina empregaram personagens nativos em alegorias nacionais, muitas vezes nos moldes de James Fenimore Cooper. ${ }^{60}$ Num exemplo famoso, escrito em 1865,

58 UNANUE, Hipólito. Observaciones sobre el clima de Lima, y sus influencias en los seres organizados, en especial el hombre. Lima: [s.n.], 1806. p. 141.

59 THURNER, Mark. History's Peru: The poetics of colonial and postcolonial historiography. Gainesville, Fla.: University Press of Florida, 2012. p. 85.

60 SOMMER, op. cit. 
Iracema, uma "princesa" indígena, seduz um soldado português e dá à luz o "primeiro" brasileiro, sabendo que isso a levará à morte. Seu destino exemplifica a perspectiva do autor, José de Alencar, que pensou o Brasil, escreve Doris Sommer, como "especial, não por resistência heroica, mas por causa da rendição romântica". ${ }^{61}$ Ideias análogas infundiram a literatura de viagens. Em 1852, um naturalista suíço escreveu: "Durante a conquista espanhola, um grande número de índios cometeu suicídio por desespero". ${ }^{2}$ Como muitos contemporâneos (e sucessores), ele tomou os conquistadores e o clero à letra, ajudando assim a inscrever os relatos coloniais de conquista no imaginário racial dos autores do século XIX e de seus leitores. Clements Markham, oficial da marinha britânica, geógrafo e explorador que coletou sementes de cinchona nos Andes e as transportou para plantações coloniais na Índia, encontrou "vestígios" do "tempo dos incas" em um poema peruano sobre uma divindade nativa que "meditaria sobre o suicídio por causa de seu amor por Ccorittica (a flor de ouro)". Markham se maravilhou: "Quão verdadeira é essa ideia de alguém meditar sobre o suicídio, indignado com o temeroso contraste entre a face calma e bela da natureza e as tristezas desenfreadas e as paixões tempestuosas de sua própria mente não instruída". ${ }^{63}$ Como muitos antes dele, Markham colocou o suicídio em termos de gênero, neste caso, emasculando a figura nativa como emocional e intelectualmente subdesenvolvida.

Outros traficaram narrativas de extermínio negro, especialmente onde mitologias nacionais emergiram em torno de identidades brancas ou mestiças fictícias que excluíam pessoas de ascendência africana. ${ }^{64}$ Mas, embora os observadores das Américas tenham usado o suicídio para explicar ou prever o desaparecimento de povos negros e nativos, novos discursos, como os de seus antecedentes coloniais, também funcionaram para distinguir e separar. O estadista cubano José Antonio Saco descreveu os escravos negros do Caribe como sempre prontos a lutar pela "liberdade" e os justapôs aos primeiros habitantes da região, "quase todos os quais morreram de fadiga, suicídio e varíola". ${ }^{65}$

\footnotetext{
61 ALENCAR, José Martiniano de. Iracema: A novel. Traduzido por Clifford E. Landers. Nova York: Oxford University Press, 2000. SOMMER, op. cit., p. 150.

62 TSCHUDI, J. J. von. Travels in Peru, during the years 1838-1842. Nova ed. Traduzida por Thomasina Ross. Nova York: Putnam, 1852. p. 349.

63 MARKHAM, Clements R. Cuzco: A journey to the ancient capital of Peru. London: Chapman and Hall, 1856. p. 190 e 191.

64 O exemplo clássico é a Argentina. ANDREWS, George Reid. The Afro-Argentines of Buenos Aires, 1800-1900. Madison, Wis.: Univervity of Wisconsin Press, 1980.

65 SACO, José Antonio. Historia de la esclavitud de la raza africana en el Nuevo Mundo y en especial en los países Américo-hispanos. Barcelona: [s.n.], 1879. p. 134.
} 
O espectro da rebelião negra também afetou a abordagem dos abolicionistas em relação ao suicídio escravo. Isso aconteceu especialmente em Cuba, onde as prolongadas lutas pela abolição (1886) e pela independência (1902) frequentemente se entrelaçavam. Em 1819, as autoridades enganaram e emboscaram Ventura "Coba" Sanchez, líder de uma comunidade de escravos fugitivos. De acordo com um relatório oficial, ele então "preferiu se afogar no rio Quivijan em vez de se render" ${ }^{66}$ Verdadeira ou não, a história ganhou proeminência literária apenas no século $X X{ }^{67}$ Até então, um poderoso ex-escravo, que morreu por sua própria mão, não tinha fornecido o tipo de imagem que até os abolicionistas queriam abraçar. O declínio do comércio de escravos, em meados do século XIX, e a subsequente elevação do capital vivente contribuíram ainda mais para essa dinâmica, assim como o medo duradouro da insurreição negra fez com que uma figura como Coba fosse perigosa, mesmo (ou especialmente) para os abolicionistas. ${ }^{68}$

Dinâmicas semelhantes prevaleceram no Brasil, onde os proprietários de escravos se apegaram ao argumento de que a abolição destruiria a economia nacional. Nos Estados Unidos, os defensores da escravidão também argumentaram com base na economia, mas toda uma classe de fazendeiros também defendeu a instituição em termos morais, colocando-a como um "bem positivo". ${ }^{69} \mathrm{Na}$ América Latina, esse tipo de defesa moral era menos comum. Os proprietários brasileiros até professavam oposição ética à escravidão, que, segundo eles, precisava ser preservada para evitar a ruína financeira nacional. Defendendo a escravidão nesses termos - e evitando um argumento moral - os senhores de engenho brasileiros podem até parecer progressistas e favoráveis ao fim da escravidão, mesmo enquanto perseveravam nisso por duas décadas a mais do que nos Estados Unidos. ${ }^{70}$

66 Citado e traduzido por: FRANCO, Jos'e L. Maroons and slave rebellions in the Spanish territories. In: PRICE, Richard. (org.). Maroon societies: Rebel slave communities in the Americas. $3^{a}$ ed. Baltimore: Johns Hopkins University Press, 1996. p. 35-48. p. 43.

67 HEWITT, Julia Cuervo. Voices out of Africa in twentieth-century Spanish Caribbean literature. Lewisburg, PA.: Bucknell University Press, 2009. p. 369, nota 152. FAR. Dirección Política. Historia de Cuba. La Habana: Editorial de Ciencias Sociales, 1985. p. 121-123. LEANTE, Ce'sar. Los guerrilleros negros. México, DF: Siglo Veintiuno, 1979. LUIS, William. Literary bondage: Slavery in Cuban narrative. Austin, TX.: University of Texas Press, 1990. cap. 5.

68 PÉREZ JR., op. cit., p. 48. Duas importantes exceções - romances que usaram relatos de suicídio de escravos para chamar a atenção para os horrores da escravidão - são: SUÁREZ, Anselmo; ROMERO, Mario Cabrera y Saqui. Francisco, el ingenio; o las delicias del campo: novela cubana. Miami: Mnemosyne Publishing, 1969. Original de 1947. VILLAVERDE, Cirilo. Cecilia Valdés, or EI Angel Hill. Traduzido por Helen Lane. Oxford: Oxford University Press, 2005. Original de 1882. "Positive good" em oposição a "necessary evil".

70 WEINSTEIN, Barbara. The decline of the progressive planter and the rise of subaltern agency: Shifting narratives of slave emancipation in Brazil. In: JOSEPH, Gilbert M. (org.). Reclaiming the political in Latin American history: Essays from the North. Durham, N.C.: Pantheon Books, 2001. p. 81-101. Weinstein baseia-se em observações feitas anteriormente por, entre outros,: GENOVESE, Eugene D. The world the slaveholders made. Nova York: Pantheon Books,1969. TOPLIN, Robert Brent, The abolition of slavery in Brazil. New York: Atheneum, 1971. 
A relativa ausência de argumentos como o "bem positivo", evidentemente, não tornou os senhores de escravos latino-americanos benevolentes ou menos cruéis; eles se beneficiavam quando a escravidão era debatida em termos econômicos e não morais. Em todo o mundo atlântico, os proprietários hipotecaram seus escravos, mas a prática raramente era discutida publicamente nos Estados Unidos, onde funcionava como o que Bonnie Martin chama de "motor invisível da escravidão". ${ }^{71}$ No Brasil, por outro lado, a alavancagem de garantias humanas operou de forma mais aberta, especialmente durante e após os últimos dias da escravidão, quando os proprietários foram compensados pelas perdas financeiras incorridas pela Abolição. Essa compensação exigiu inventário público, um exemplo tão simples quanto qualquer capital que empurra a moralidade para fora do cenário e reduz os seres humanos a nada mais que ativos financeiros. ${ }^{72}$ Quando a escravidão era desafiada em bases morais, o suicídio poderia galvanizar os esforços abolicionistas. Mas quando o capital dominava o debate, a autodestruição poderia ser mais facilmente reduzida aos termos frios e brutais dos comerciantes e proprietários de escravos, que a consideravam, em primeiro lugar, como a perda de propriedade.

No Atlântico Norte, o uso abolicionista do suicídio de escravos floresceu após a publicação, em 1773, do poema The dying negro, escrito por dois britânicos e apresentando um escravo que se apunhala em busca de liberdade e redenção cristã. ${ }^{73}$ O famoso romance abolicionista de Aphra Behn, Oroonoko, e sua adaptação para o teatro, tão popular no Norte, deixaram marcas mais sutis no Sul. Publicado pela primeira vez em 1688, o romance foi adaptado para o palco sete anos depois e, em seguida, apresentado continuamente na Grã-Bretanha por mais de um século. Mas em 1795 as apresentações da peça foram proibidas em Charleston, na Carolina do Sul, e, até onde sabemos, nunca chegaram ao palco em Kingston, na Jamaica. ${ }^{74}$ Embora tenha como cenário o Suriname, não foi traduzido para o holandês até o século $X X{ }^{75}$ As versões em espanhol e português chegaram tardiamente e a obra não parece ter sido mencionada nem mesmo nos periódicos brasileiros do século XIX. Enquanto isso, o suicídio de escravos tornou-se um acontecimento tão constante no Norte que alguns

71 Bonnie Martin, Slavery's invisible engine: Mortgaging human property. Journal of Southern History, v. 76, n. 4, p. 817-866, 2010. p. 819.

72 NARO, Nancy Priscilla. A slave's place, a master's world: Fashioning dependency in rural Brazil. Nova York: Bloomsbury Academic, 2000. p. 153-155.

73 DAY, Thomas; BICKNELL, John. The dying negro: A poetical epistle. London: [s.n.], 1773). Ver BELL, op. cit., p. 204-208; SNYDER, op. cit., p. 13-14, 121-127.

74 BEHN, A. Oroonoko; or, The royal slave: A true history. London: [s. n.], 1688. Ver SNYDER, op. cit., p. 106-107.

75 PHAF-RHEINBERGER, Ineke. Introduction: A mosaic setting: A Contrastive history of genre. In: ARNOLD, A. James (org.). A history of literature in the Caribbean: English and Deutch speaking countries. Amsterdam: John Benjamins, 2001.p. 471-477. p. 473. 
fazendeiros britânicos projetavam empatia e angústia sobre suas tendências ao suicídio, considerando-os, contraditoriamente, aptos à escravidão e ao mesmo tempo imbuídos de uma paixão exclusivamente inglesa pela liberdade. ${ }^{76}$

Embora os abolicionistas brasileiros também tenham atacado a escravidão como imoral, o fato de que seus oponentes mais fortes muitas vezes defendiam a instituição em termos econômicos deixava pouco espaço para o suicídio funcionar como uma crítica a ela. Mesmo que todos alegassem concordar que a escravidão era um mal, por outro lado as poderosas histórias de suicídio eram, de certo modo, descartadas. O medo da rebelião de escravos e do colapso econômico pós-abolição fechou ainda mais a abertura. Entendido em termos econômicos e ligado a medos pós-abolicionistas apocalípticos, o suicídio de escravos era uma ferramenta menos eficaz para os abolicionistas brasileiros e cubanos do que para seus pares no Atlântico Norte. ${ }^{77}$

A diferença entre o Norte e o Sul é ainda mais evidente nas abordagens abolicionistas a Zumbi. ${ }^{78}$ Os intelectuais brasileiros começaram a escrever sobre o líder quilombola, com frequência crescente, no século XIX. Mas, mesmo quando sua história emergiu em histórias nacionais e regionais, os abolicionistas a evitavam cuidadosamente. O poema Saudação a Palmares, de Castro Alves, de 1870, talvez a única obra abolicionista brasileira dedicada ao quilombo, não menciona Zumbi. ${ }^{79} \mathrm{O}$

BROWN, 2007, op. cit., p. 154.

77 Parece plausível que o longo alcance da Igreja católica, que olhou vagamente para o suicídio, possa também ajudar a explicar sua relativa ausência no discurso abolicionista latino-americano. Como em Cuba, a evitação geral do suicídio pelos abolicionistas brasileiros não foi sem exceção. Por exemplo, a peça Mãe, de José de Alencar, escrita em 1859, apresenta um escravo que se mata, um ato, segundo João Albuquerque, que mantém "uma das imagens mais apreciada do escravo, a do escravo como o paradigma da devoção cega". ALBUQUERQUE, Severino João. The Brazilian theatre up to 1900. In: ECHEVARRÍA, Roberto González, Roberto; PUPO-WALKER, Enrique. (org). The Cambridge history of Latin American literature. v. 3: Brazilian literature; bibliographies. Cambridge: Cambridge University Press, 1996. p. 118. DUKE, Dawn. Literary passion, ideological commitment: Toward a legacy of Afro-Cuban and Afro-Brazilian women writers. Lewisburg, PA: Bucknell University Press, 2008. p. 223, nota 5.

78 Introduções úteis a Zumbi e Palmares incluem: CARNEIRO, Edison. O quilombo do Palmares, 1630-1695. São Paulo: Brasiliense, 1947. FRANÇA, Jean Marcel Carvalho; FERREIRA, Ricardo Alexandre. Três vezes Zumbi: a construção de um herói brasileiro. São Paulo: Três Estrelas, 2012. GOMES, Flávio dos Santos. De olho em Zumbi dos Palmares: Histórias, símbolos e memória social. São Paulo: Claro Enigma, 2011. Idem. Mocambos dos Palmares: histórias e fontes (séc.. XVI-XIX). Rio de Janeiro: 7 Letras, 2010. REIS, Andressa Mercês Barbosa dos. Zumbi: Historiografia e imagens. 2004. Dissertação (Mestrado em História) - Universidade Estadual Paulista, Franca, 2004. SCHWARTZ, Stuart B. Slaves, peasants, and rebels: reconsidering Brazilian slavery. Urbana, III.: University of Illinois Press, 1996. Cap. 4.

79 GRADEN, Dale T. History and motive as seen through Antônio Frederico de Castro Alves's "Saudação a Palmares", Brasil/Brazil, v. 6, n. 9, p. 27-45, 1993. Albuquerque, escritor proeminente, escreveu um poema sobre Palmares, onde destaca o suicídio de Zumbi. Reveladoramente, a peça foi publicada em 1889, no primeiro aniversário da abolição. ALBUQUERQUE, José Joaquim de Campos da Costa de Medeiros e. Palmares, Treze de Maio, v. 2, n. 7, p. 39-44, 1889. 
famoso estadista e advogado antiescravidão Joaquim Nabuco mencionou e valorizou Palmares e Zumbi, mas os chamou de "fato isolado em nossa história". ${ }^{80}$

Que os abolicionistas brasileiros fossem cautelosos em seu tratamento é algo inesperado, dado o fato de que duas décadas após a Abolição, o antropólogo criminal Raymundo Nina Rodrigues tenha celebrado Palmares, mas criticado aqueles que "quase lamentariam sua destruição". Os brasileiros precisavam abandonar sua recém-descoberta "idolatria incondicional pela liberdade" e agradecer aos verdadeiros heróis da história - as forças coloniais que derrotaram Zumbi e destruíram "as maiores ameaças à civilização do futuro povo brasileiro, este novo Haiti, resistente ao progresso e inacessível à civilização". Os brasileiros precisavam abandonar sua recém-descoberta "idolatria incondicional pela liberdade" e agradecer aos verdadeiros heróis da história - as forças coloniais que derrotaram Zumbi e destruíram "as maiores ameaças à civilização do futuro povo brasileiro, este novo Haiti, resistente ao progresso e inacessível à civilização". ${ }^{81}$ Num país onde o medo da rebelião negra perdurou até o século XX, uma figura tão opositora e ameaçadora quanto Zumbi não se prestava a ser um símbolo abolicionista viável. Os abolicionistas brasileiros, em vez disso, empregaram outros tropos de persuasão moral (por exemplo, a proteção paternalista às mulheres escravas e seus ventres), ao mesmo tempo em que contavam com argumentos de que a escravidão impedia o desenvolvimento industrial ou o crescimento populacional. ${ }^{82}$ Os ativistas também promoveram sua causa, conectando-se a outros movimentos sociais e explorando as rivalidades políticas e o crescente sentimento de que a escravidão impedia 0 progresso nacional e deixava o Brasil cada vez mais isolado e atrasado. ${ }^{83}$

Em contrapartida, os abolicionistas negros e editores da revista The AngloAfrican Magazine, de Nova York, foram pouco cautelosos quando publicaram um

80 NABUCO, Joaquim. A escravidão (1870). Recife: [s.n.], 1988. p. 108. De passagem, Silvia Lara trata os textos de Nabuco e Castro Alves como evidência do uso abolicionista brasileiro de Zumbi e Palmares, mas sem citar outros exemplos. O trabalho de Lara sobre Palmares não é nada menos do que inovador, mas neste ponto, e especialmente quando lido ao lado de abolicionistas do Atlântico Norte, eu acredito que Nabuco e Castro Alves são mais bem entendidos como exceções importantes do que como ilustrações de uma tendência maior. LARA, Silvia Hunold. Do singular ao plural: Palmares, capitães-do-mato e o governo dos escravos. In: REIS, João José; GOMES, Flávio dos Santos (org.). Liberdade por um fio: História dos quilombos no Brasil. São Paulo: Companhia das Letras, 1996. p. 81-109. p. 99.

81 RODRIGUES, Raymundo Nina. Troya negra: erros e lacunas da história de Palmares. Revista do Instituto Arqueológico e Geográfico Pernambucano, v.11, n. 63, p. 645-672, 1904. p. 652-653.

82 AZEVEDO, Célia M. Marinho de. Abolitionism in the United States and Brazil: A comparative perspective. New York: Garland Pub., 1995. COWLING, Camillia. Conceiving freedom: Women of color, gender, and the abolition of slavery in Havana and Rio de Janeiro. Chapel Hill, N.C.: University of North Carolina Press, 2013.

83 Por exemplo: BEATTIE, Peter M. Punishment in paradise: Race, slavery, human rights, and a nineteenth century penal colony. Durham, N.C.: Duke University Press, 2015. MACHADO, Maria Helena. O plano e o pânico: os movimentos sociais na década da abolição. Rio de Janeiro: UFRJ, 1994. 
artigo da poeta afro-americana Frances Ellen Watkins Harper, em 1860, apresentando ninguém menos que Zumbi, cujas ações projetaram "esperança de ver um futuro de progresso e bem-estar para nossa raça". ${ }^{84}$ Zumbi e seus seguidores "resolveram não ser capturados vivos; a morte em uma de suas formas terríveis estava diante deles; mas eles correram esse risco em preferência ao cativeiro". ${ }^{85} \mathrm{O}$ fato de a narrativa do suicídio de Zumbi ter encontrado seu caminho no abolicionismo norte-americano, enquanto cuidadosamente evitado por ativistas brasileiros, destaca as diferentes trajetórias regionais do suicídio. No Atlântico Sul, os defensores do antiescravismo permaneceram mais cautelosos do que seus pares no Atlântico Norte, mesmo que outros em torno deles tenham começado a escrever sobre Zumbi e outros mártires não brancos com frequência cada vez maior. ${ }^{86}$

Nas décadas após a Independência, o suicídio continuou a marcar a diferença racial. Quando discutido em relação aos povos nativos, funcionava mais frequentemente como uma metáfora ou explicação para a extinção e um meio de distanciar as novas nações de suas origens indígenas "atrasadas". Embora dinâmicas semelhantes pudessem marcar as discussões sobre o suicídio negro, o medo da rebelião de escravos, a relação entre abolição e independência e a duradoura importância econômica da escravidão, impuseram limites claros à eficácia do suicídio como um tropo antiescravista na América Latina. Essa diferença exemplifica o desequilíbrio arquivístico do suicídio. Como evidência da extinção nativa, o suicídio se encaixava melhor nas narrativas nacionais emergentes do que em contextos em que a escravidão é que se destacava como um nó no corpo político. Sua comparativa ausência no discurso abolicionista do Atlântico Sul, então, dificilmente fica sem sentido. Pelo contrário, o silêncio e a estudada evitação exemplificam a capacidade do suicídio de moldar as discussões sobre raça e nação de múltiplas maneiras.

O poder do silêncio - e a importância de examinar as ausências paralelamente à presença - fica claro nas divergentes trajetórias pós-independência de Zumbi e numa história semelhante da Amazônia, onde em 1727 soldados portugueses capturaram Ajuricaba, um índio manaú, alinhado com europeus rivais. Preso num barco, ele e alguns companheiros cativos se amotinaram. Apesar de estar acorrentado, Ajuricaba atirou-se ao mar. As autoridades coloniais consideraram o ato

84 RUSTIC, Jane [Frances Ellen Watkins Harper]. Zombi, or Fancy Sketches. Anglo-African Magazine, Feb. 1860, p. 33-37. p. 36. Sou grato a Juan Suarez Ontaneda por esta referência.

85 Ibidem. Esta linguagem, vale a pena salientar, é muito semelhante à usada por Barbot.

86 Essa diferença é especialmente notável, dada a coincidência entre redes abolicionistas no Brasil, em Cuba e no Atlântico Norte. AZEVEDO, op. cit. 
um suicídio, conclusão que os poucos historiadores que mencionam Ajuricaba aceitam como inteiramente verdadeira. ${ }^{87}$

Até que ponto a história de Ajuricaba circulou durante o século XVIII não é claro. Após a Independência, ela ganhou limitada visibilidade regional. Em 1863, um jornal do Nordeste referiu-se a Ajuricaba numa exortação mais longa para os brasileiros abraçarem sua história indígena. O escritor comparou-o ao governante asteca Cuauhtémoc e a Hatuey, o lendário guerreiro indígena que lutou contra os espanhóis em Cuba. ${ }^{88}$ Um almanaque amazônico, publicado em 1884, elogiava a "tenacidade" de Ajuricaba e a força de vontade para morrer por uma causa maior. $\mathrm{Na}$ mesma época, um navio comercial e uma loja em Manaus levavam seu nome. ${ }^{89}$ Nabuco incluiu Ajuricaba num estudo mais amplo sobre a lei brasileira, publicado pela primeira vez em 1903, e, em 1931, um historiador da Amazônia o chamou de "o primeiro a lutar pela liberdade na América". 90

Em contraste com Ajuricaba, que se tornou um símbolo regional, mas não nacional, a estrela de Zumbi cresceu gradualmente ao longo do século XIX, depois mais acentuadamente após a Abolição (1888) e a transição da monarquia independente para a República (1889). Por volta das décadas de 1920 e 1930, ele era uma referência cultural amplamente reconhecida e hoje é uma das figuras históricas mais proeminentes do país, comemorado em desfiles de carnaval e na parada do Dia Nacional da Consciência Negra, em 20 de novembro, data em que se celebra sua morte. Embora a memória de Ajuricaba seja mantida em pequenos bolsões do Brasil, ele é amplamente desconhecido em todo o país. Seu suposto suicídio - aparentemente tão heroico quanto o de Zumbi - foi praticamente esquecido.

Esse esquecimento é indicativo de dinâmicas específicas no Brasil e mais generalizáveis nas Américas. Em contraste com a "rendição romântica" de Iracema, Ajuricaba morreu lutando. O fato de ele ser da Amazônia, longe dos poderes culturais

87 FARAGE, Nadia. As muralhas dos sertões: os povos indígenas no Rio Branco e a colonização. Rio de Janeiro: Paz e Terra, 1991. p. 62-63. SWEET, David Graham. A rich realm of nature destroyed: The Middle Amazon Valley, 1640-1750. 1974. Tese (Doutorado) - Wisconsin-Madison University, 1974. p. 545-546. WRIGHT, Robin M.; CUNHA, Manuela Carneiro da. Destruction, resistance, and transformation - Southern, Coastal, and Northern Brazil (1580-1890). In: SALOMON, Frank; SCHWARTZ, Stuart B. (org.). The Cambridge history of the native peoples of the Americas: South America. Cambridge: Cambridge University Press, 1999. v. 3, parte 1, p. 287-381. p. 365.

88 SÁ, Guilherme Amazonas de. Discurso que devia ser pronunciado pelo acadêmico Guilherme Amazonas de Sá. Diario de Pernambuco, 2 set. 1863, p. 8.

89 HISTÓRIA da provincia do Amazonas (de 1540 a 1883). In: ALMANACH administrativo, historico, estatistico e mercantil da provincia do Amazonas para o anno 1884. Manaus, 1884. 90 p.; Amazonas, 19 ago. 1881, p. 3;Jornal do Amazonas, 6 maio 1886, p. 4.

90 NABUCO, Joaquim. O direito do Brasil. São Paulo: Instituto Progresso Editorial, 1949. p. 67-78. REIS, Arthur Cézar Ferreira. História do Amazonas. 2. ed. Belo Horizonte: Itatiaia, 1989. p. 102. Original de 1931. 
e políticos costeiros do Brasil, onde Zumbi e Iracema primeiro ganharam fama, também é significativo. A diferença entre Ajuricaba e Zumbi também reflete um processo maior através do qual os símbolos e as figuras africanas e negras gradualmente substituíram as imagens nativas no centro da galeria de mascotes raciais da nação. Esse processo complexo e tenso emerge, em parte, do desejo de distinguir o Brasil de seus vizinhos supostamente mestiços de indígenas e também como um produto de mobilizações políticas e culturais negras. ${ }^{91}$

As trajetórias contrastantes de Zumbi e Ajuricaba ressaltam a capacidade do suicida de enfatizar a diferença racial, não apenas entre branco e não branco, mas também entre negro e nativo. Se a história de Zumbi foi improdutiva para os abolicionistas brasileiros, em outros contextos ganhou mais força, com o suicídio funcionando como agente molestador que ajudou a transformar uma história de violência colonial em um conto mais romântico que alimentou ideias igualmente fantasiosas sobre harmonia racial e unidade nacional. Por volta da virada do século $\mathrm{XX}$, os pesquisadores começaram a escrever sobre documentos coloniais de Palmares anteriormente ignorados mostrando que Zumbi não havia cometido suicídio e sim fora morto por soldados coloniais, que decapitaram seu cadáver e postaram sua cabeça em público. Um novo documento, escreveu um pesquisador que trabalhou na Biblioteca Nacional, "põe fim à lenda do suicídio de Zumby". ${ }^{22}$ Aquela fora uma ilusão. Durante anos, a maioria dos estudos reproduziu a narrativa do suicídio, que se manteve distintiva, mesmo quando acadêmicos e ativistas a combateram vigorosa e repetidamente.

Quando a morte de Zumbi é entendida como o produto de sua própria mão, pode representar uma alternativa palatável a uma história mais terrível. A decapitação e a exibição de sua cabeça decepada para consumo público traía o tipo de violência e barbarismo que os brancos frequentemente atribuíam aos africanos. Muito mais atraente era a narrativa veiculada numa história nacional influente, escrita em 1822, ano em que o Brasil declarou independência, que descreveu como Zumbi e seus guardas "voluntariamente se lançaram do alto do pico, não querendo sobreviver à custa de perder a liberdade". ${ }^{33}$ Nas décadas seguintes, histórias regionais e nacionais incorporaram relatos semelhantes, assim também os escritores estrangeiros. Em 1857, os reverendos norte-americanos DP Kidder e JC Fletcher escreveram: "Quando toda a esperança se foi, [Zumbi] e o mais resoluto dos seus

91 Para uma visão geral, ver: BORGES, Dain. The recognition of Afro-Brazilian symbols and ideas, 1890-1940. Luso-Brazilian Review, v. 32, n. 2, p. 59-78, 1995.

92 BEHRING, Mario. A morte do Zumby. Kosmos, v. 3, n. 9, 1906.

93 DENIS, Fernando. O Brasil. v. 2. Salvador: Progresso, 1955. p. 94. 
seguidores retirou-se para o cume de uma rocha alta dentro do cerco e, preferindo a morte à escravidão, atiraram-se do precipício". Dos capturados vivos, "um quinto dos homens foi selecionado para a Coroa: o restante foi dividido entre os captores como seu saque". ${ }^{94}$

Essas narrativas chegaram ao trabalho acadêmico. Cerca de 60 anos depois, o historiador da Universidade da Califórnia, Charles Chapman, escreveu: "Vendo que sua causa estava perdida e sem reparo, Zumbi se lançou do penhasco, e sua ação foi seguida pelos mais distintos de seus guerreiros. Alguns foram de fato capturados, mas talvez seja um tributo a Palmares, apesar de horrível, que [os que não se mataram] tenham sido todos mortos; não era seguro escravizar esses homens, apesar do valor de seu trabalho". ${ }^{95}$ Como Kidder e Fletcher, Chapman relacionou o suicídio ao valor econômico. Enquanto os senhores rangiam os dentes com o impacto financeiro que acompanhava o suicídio de escravos, a morte de Zumbi podia ser expressa em termos diferentes - de posição heroica de um precursor amante da liberdade da nação. Seu suicídio tirou, assim, o sangue das mãos dos ancestrais coloniais do Brasil, os absolveu de sua morte e ajudou a transformar a violência colonial e o racismo numa narrativa fictícia de harmonia racial que, embora de forma improvável, se enraizou numa nação que preservou a escravidão por mais tempo do que qualquer outra nas Américas, onde até mesmo no século XX os comentaristas poderiam usar Palmares para evocar o Haiti.

Se os euro-brasileiros temeram o espectro da violência negra, no Peru a paranoia racial se concentrou principalmente nos indígenas. Apesar da significativa presença de escravos africanos durante a era colonial, especialmente após a independência (1824) e a abolição (1854), observadores nacionais e estrangeiros enfatizavam as origens nativas e espanholas do Peru, colocando assim a nação na América "índia". Na segunda metade do século XIX, as elites peruanas "redescobriram" a cultura indígena como parte de um processo hispano-americano de abrangência regional que, escreve Rebecca Earle, utilizou a "história précolombiana para construir um passado nacional que dava pouco espaço às populações indígenas contemporâneas". ${ }^{96}$ Cahuide, o inca que se matou enquanto lutava contra os espanhóis em Sacsayhuamán, se encaixava perfeitamente nessa narrativa.

94 KIDDER, D. D.; FLETCHER, J. C. Brazil and the Brazilians, portrayed in historical and descriptive sketches. Philadelphia: Childs \& Peterson, 1857. p. 512 e 513.

95 CHAPMAN, Charles E. The negro numantia. Journal of Negro History, v. 3, n. 1, p. 29-32, 1918. p. 32.

96 EARLE, Rebeca. The return of the native: Indians and myth-making in Spanish America, 18101930. Durham, N.C.: Duke University Press, 2007. p. 183. 
Dois escritores estrangeiros - William H. Prescott, que havia estudado em Harvard, e Sebastian Lorente, escritor espanhol de enorme influência e residente no Peru - reinseriram Cahuide no registro escrito em meados do século XIX ${ }^{97}$ A primeira referência conhecida é a crônica apócrifa das proezas espanholas. ${ }^{98}$ Durante séculos, a versão original desse texto esteve perdida, e os estudiosos consultaram cópias que, por razões desconhecidas, omitem o nome de Cahuide, mesmo quando detalham seus atos heroicos. Dois relatos do início da década de 1570, um de um nobre inca e outro do conquistador Pedro Pizarro, descrevem o suicídio em Sacsayhuamán, sem identificar o combatente. ${ }^{99}$ Como o nome de Cahuide entrou novamente no registro histórico é um mistério. Na década de 1940, o estudioso peruano Francisco Loayza dedicou um volume inteiro ao tema, mas foi incapaz de tirar conclusões convincentes e acabou sendo forçado a mudar o título de seu livro de Cahuide não existiu para o decididamente menos provocativo Cahuide não se chamava Cahuide. ${ }^{100}$

Assim como a de Zumbi, a morte de Cahuide forneceu um final relativamente limpo para uma confusa e aterradora história colonial. "Com a derrota do Cahuide", escreveu Lorente, "suas tropas vacilaram e cerca de 1.500 se renderam sem maior resistência". ${ }^{101}$ Prescott bateu em teclas semelhantes. Pizarro, explicou ele, respeitava Cahuide e tentava capturá-lo vivo. "Mas o chefe inca não seria capturado; e, achando que resistir mais era ineficaz, saltou para a beirada das ameias e, jogando para longe sua clava, envolveu-se no manto e se jogou de cabeça do topo. Ele morreu como um romano antigo. Ele havia dado seu último golpe pela liberdade de seu país, e desdenhava de sobreviver à sua desonra". ${ }^{102}$ Assim como aconteceu com Zumbi, o suicídio de Cahuide removeu o sangue das mãos coloniais; Pizarro queria capturá-lo vivo, mas foi ele que escolheu se matar. O heroísmo de Cahuide também contrasta com as noções que prevaleceram sobre a fragilidade dos nativos e mostra

97 LORENTE, Sebastián. Historia de la conquista del Perú. Lima: Arbieu, 1861. PRESCOTT, William Hickling. Historia de la conquista del Perú: Con observaciones preliminares sobre la civilización de los Incas. Madrid: Gaspar y Roig, 1853. Lorente "escreveu quase sozinho a primeira geração de textos republicanos de história do Peru pós-colonial". THURNER, op. cit., p. 125.

98 "Relación del sitio del Cuzco y principio de las guerras civiles del Perú hasta la muerte de Diego de Almagro".

99 PIZARRO, Pedro. Descubrimiento y conquista del Perú. Ed. Horacio H. Urteaga. Lima: Imp. y Librería de Sanmartí y Ca., 1917. CASTRO YUPANGUI, Diego de. Relación de la conquista del Perú y hechos del Inca Manco II. Ed. Horacio H. Urteaga y Carlos Alberto Romero. Lima: SanMartí, 1916.

100 LOAYZA, Francisco A. Cahuide no existiu: Ensayo crítico-histórico, basado en antiguos documentos irrefutables. Lima: Editorial de D. Miranda, 1944; 1948.

101 LORENTE, op. cit., p. 299.

102 PRESCOTT, William H. History of the conquest of Peru. v. 2. Ed. Wilfred Harold Munro. Philadelphia: J. B. Lippincott, 1904. p. 285. 
uma forma de protagonismo em geral negada aos não brancos. Mas é claro que havia limites estreitos para esse nascente discurso.

Em 1870, o novo gran reloj de Lima incluiu um painel representando "A Imolação de Cahuide durante a Batalha de Sacsayhuamán" (ver Figura 1). No início do século $\mathrm{XX}$, ele era um marco dos relatos históricos patrióticos. Atores representaram a defesa de Sacsayhuamán, em 1920, quando a Universidade de Cuzco concedeu um título honorário a Woodrow Wilson e, em 1924, quando o general John J. Pershing visitou o Peru. ${ }^{103} \mathrm{O}$ general e autor Felipe de la Barra criticou duramente a sugestão de Loayza de que Cahuide "não existiu", explicando entusiasticamente (embora sem resolver os mistérios que cercam seu nome) que ele era um componente central da "educação moral" de crianças em idade escolar e de soldados. O nome de Cahuide abrilhantava os postos militares ao longo da fronteira nacional, edifícios militares e veículos, nomes de ruas em cidades por todo o país, clubes esportivos e revistas literárias. ${ }^{104}$ Barra o chamou de "índio peruano intrépido e galante que defendeu o último bastião de Sacsayhuamán e destruiu-se antes de cair nas mãos do inimigo". ${ }^{105}$ Tamanho heroísmo serviu de modelo aos peruanos modernos, incluindo "um soldado que viu a iminente captura da bandeira com a qual ele havia guiado seus homens para o combate, e a fim de salvá-la das mãos inimigas e de não cair prisioneiro, segurou-a e pulou do penhasco". ${ }^{106}$ Barra pode estar se referindo a uma batalha durante a Guerra do Pacífico (1879-1883), ou pode facilmente ter inventado a história. Independentemente disso, o significado da estória é claro. Por meio de Cahuide, certas formas de suicídio nativo podiam representar algo que raramente foram antes: bravura e uma fonte de força nacional.

A masculinidade facilitou essa transformação. Um poema de 1898 chamava Cahuide de "leão" e "grande guerreiro". ${ }^{107}$ Em 1901, o artista peruano José Effio o pintou numa imagem claramente inspirada por uma ilustração na Historia de la conquista de Peru, de Prescott (ver Figura 2). Loayza descreveu a defesa de Sacsayhuamán como "a luta da virilidade indígena contra a invasão estrangeira", liderada pela "figura de um autêntico peruano, de um guerreiro índio, conglomerado de músculos de aço, sangue viril e uma disposição inflexível para luta". O homem

\footnotetext{
103 BARRA, Felipe de la. El indio peruano en las etapas de la conquista y frente a la republica. Lima: Propaganda y Publicaciones Militares, 1948. p. 12. Um emissário recebeu o título em nome de Wilson.

104 Ibidem, p. 12-13.

105 Ibidem, p. 7.

106 Ibidem, p. 12, nota 5.

107 MONTOYA, Arturo. Cahuide. In: MONTOYA, Arturo. Medallones. Lima: [s.n.], 1898. p. 14.
} 
que a história se lembraria como Cahuide, escreveu Loayza, era um "grande representante de nossa raça". ${ }^{108}$

Considerado ao lado de Zumbi e Ajuricaba, Cahuide revela a capacidade do suicídio de realizar múltiplos tipos de diferenciação racial. A ascensão de Zumbi e o esquecimento de Ajuricaba ajudaram o Brasil a abraçar - de forma limitada e estreita - sua emergente identidade "afro", deixando para trás seu passado nativo. A ascensão de Cahuide sinaliza uma trajetória oposta no Peru, onde figuras nativas entraram em discursos nacionais e pessoas descendentes de africanos foram empurradas cada vez mais para as margens da história nacional. Em ambos os casos, a branquitude ou uma mestiçagem embranquecida tornou-se um ideal, capaz de incorporar simultaneamente histórias não brancas e marginalizar pessoas não brancas no presente. A heroica capitulação de combatentes negros ou indígenas serviu como uma metáfora de sacrifício que abriu caminho para a construção de futuras nações civilizadas. Como Cahuide, cuja morte em combate contra invasores espanhóis tornou-se um meio de projetar uma história mítica de origens mestiças, Zumbi ajudou a gerar uma estória de unidade nacional que transformou um exemplo muito real de resistência negra violenta num relato mais romântico de rendição e harmonia racial. Em ambos os casos, a dissociação entre o suicídio e a produção colonial ajudou a pavimentar o caminho para o martírio. Cahuide estava muito longe do nativo fraco que supostamente perecera sob a pressão do trabalho colonial e, assim, abrir caminho para a escravidão africana. Embora Zumbi, ao morrer, tenha privado um pretenso dono de seu futuro trabalho, ele e os outros quilombolas já haviam escapado da escravidão. De fato, como Rodrigues argumentaria mais tarde, suas mortes se encaixaram melhor em narrativas nacionais emergentes quando foram entendidas como abertura de caminho para o "progresso" e a "civilização". ${ }^{109}$ Nesse caso, e em contraste direto com os escravos cujas mortes autoinfligidas poderiam causar estragos às finanças de um proprietário de escravos, o suicídio de Zumbi ajudou a remover um obstáculo ao sistema escravista colonial.

Se a independência e a abolição forçaram as nações americanas a confrontar e reconhecer grupos não brancos de novas maneiras, o suicídio ressalta os limites desses processos. A esses personagens excepcionais, nativos e negros, antes considerados selvagens sem nome e sem rosto, que, por impotência ou agressividade, acabaram com suas vidas, após a independência, foi permitido um pouco do que poderia ser chamado de protagonismo sobre suas próprias vidas. Onde

108 LOAYZA, op. cit., 1944; 1948, p. 7, 10.

109 RODRIGUES, op. cit. p. 652-653. 
os observadores haviam acreditado que forças "naturais", patológicas e biológicas enviavam ondas prematuras de homens e mulheres à morte por suas próprias mãos, os comentaristas modernos abraçaram a ideia de que Cahuide e Zumbi tomaram decisões conscientes de se matar. No processo, seus suicídios se enraizaram em narrativas nacionais e eles se transformaram de opositores a patrióticos.

Os discursos ligados a Cahuide e a Zumbi foram bastante flexíveis para abdicar de ideias mais antigas, mas também tacanhos o suficiente para manter figuras heroicas permanentemente presas ao passado. Mais do que extinguir velhas ideias, as histórias de mártires não brancos serviram como exceções a regras mais gerais, uma dinâmica particularmente evidente na maneira como o suicídio permaneceu vinculado a antigas noções de raça e trabalho forçado após a abolição, apesar de histórias excepcionais como as de Cahuide e Zumbi.

Em 1878, o naturalista britânico Henry Walter Bates publicou um livro sobre suas viagens pelas Américas. $O$ enorme texto de Bates menciona a autodestruição duas vezes - uma referência de passagem a bolivianos afluentes e beberrões que raramente se matavam e uma discussão mais longa sobre "manias assassinas e suicidas", no Brasil:

Um método singular de retaliação, às vezes alimentado pelos escravos em uma plantation, consiste em uma espécie de suicídio em massa. Eles tomarão uma resolução geral de se envenenarem e a levarão a cabo com o maior estoicismo... A conclusão a que este escritor sensato chegou, depois de muita experiência e sincera consideração ... foi que o único evento que poderia envolver a ruína do Brasil seria a emancipação dos escravos antes que 0 Estado tivesse previamente proporcionado uma mudança. ${ }^{110}$

Felizmente, explicou Bates, leis antivadiagem e outras medidas cautelares estavam sendo postas em prática. Em todas as Américas, no pós-abolição, as leis contra a vadiagem foram pareadas a projetos para substituir os escravos por uma nova fonte de trabalho forçado, os coolies asiáticos, cuja presença atingiu o auge na segunda metade do século XIX, e cujos suicídios demonstram como a autodestruição permaneceu racializada e ligada ao capital e ao trabalho, mesmo após o fim da escravidão. Em nome de 165 trabalhadores chineses, Li Chao-ch'un enviou uma petição à Comissão Britânica de Cuba, que investigava as condições do tráfico de coolies. A petição dizia, em parte: "Não podemos estimar as mortes que, no todo, decorreram de doenças, pancadas, fome, sede ou suicídio, saltando para o mar". ${ }^{111}$

110 BATES, Henry Walter. Central America, the West Indies and South America. $3^{\mathrm{a}}$ ed. London: E. Stanford, 1885. p. $422-424$.

111 CUBA COMMISSION. Chinese emigration: Report of the Commission Sent by China to Ascertain the Condition of Chinese Coolies in Cuba. Taipei: Cheng Wen, 1970. p. 12. Original de 1876. 
Clements Markham, o britânico que avaliava "as tristezas incontidas e as paixões tempestuosas" do suicídio inca, foi menos filosófico ao discutir os trabalhadores chineses, que eram "muito maltratados e, em consequência, frequentemente cometem suicídio". ${ }^{112} \mathrm{O}$ cônsul dos Estados Unidos no Peru informou que os guano farmers (produtores que transformavam esterco de aves marinhas em fertilizante) empregavam guardas para impedir que os guano workers (trabalhadores que transformavam esterco de aves marinhas em fertilizante) "cometam suicídio por afogamento". "A vida para o chinês", escreveu ele, "não possui recursos atraentes, e a morte... é bem-vinda para ele". ${ }^{113}$

Tal como os escravos negros, e como no caso do emprego de guardas para "proteger" os trabalhadores do guano de se matar sugere, o suicídio coolie foi entendido como uma ameaça aos empreendimentos financeiros. Uma câmara municipal cubana se reuniu, em 1864, para tratar das crescentes preocupações com o comportamento criminoso entre os escravos, pessoas livres de cor e trabalhadores chineses e, por fim, decidiram concentrar sua atenção inteiramente no assassinato e suicídio, os quais, segundo Kathleen Lopez, "impediam a rotina de uma economia de plantation". ${ }^{114}$ Um oficial da Marinha Real observou "uma forte tendência suicida" entre os trabalhadores asiáticos que construíam uma ferrovia na América Central. Quando o projeto foi finalmente concluído, o oficial explicou, ela estimulou um vibrante comércio e grande riqueza. ${ }^{115}$ Como a mais nova forma de trabalho humano cujo suicídio ameaçava os lucros, os asiáticos serviam como uma espécie de reserva macabra para espaços ocupados anteriormente por nativos e negros.

Mesmo em meio a essas mudanças, os pressupostos fundamentais permaneceram firmes ou ressurgiram em novas roupagens. Num estudo de 1882 que propunha medidas legais, morais e religiosas para prevenir o suicídio, o médico e escritor James O'Dea observou: “Há diferenças marcantes entre as raças e as nações no que se refere à tendência ao suicídio". Ele, então, erroneamente aplicou a descrição de Bates de "manias assassinas e suicidas" no Brasil à América Central. ${ }^{116}$ Tais sutilezas dificilmente pareciam importar. No final do século XIX e início do século XX, observadores como O'Dea tiraram conclusões muitas vezes baseadas diretamente nos relatos coloniais e produziram opiniões autorreferentes

112 MARKHAM, op. cit., p. 191, 38.

113 STEWART, Watt. Chinese bondage in Peru. Durham: Duke University Press, 1951. p. 97-98.

114 LÓPEZ, Kathleen. Afro-Asian alliances: Marriage, godparentage, and social status in latenineteenth-century Cuba. Afro-Hispanic Review, v. 27, n. 1, p. 59-72, 2008. p. 62.

115 PIM, Bedford. The gate of the Pacific. London: [s.n.], 1863. p. 204-205.

116 O'DEA, James J. Suicide: studies on its philosophy, causes, and prevention. New York: G. P. Putnam's Sons, 1882. p. 196-197. 
que poderiam facilmente tanto dividir negros e nativos, quanto agrupá-los com asiáticos e outros grupos "atrasados".

Muitos comentaristas da virada do século inverteram pronunciamentos anteriores, desafiando antigas conclusões sobre suicídio e primitivismo, sem preocupar-se com outros estereótipos e hierarquias. No final do século XIX, aqueles que estudavam o suicídio vinham associando cada vez mais $\mathrm{o}$ ato a populações brancas, invertendo assim os pronunciamentos anteriores. A civilização tornaria os brancos mais, e não menos, suscetíveis à autodestruição. Anos antes, dizia-se que os escravos europeus na Costa berbere eram miseráveis, mas moralmente superiores aos escravos negros no Brasil, porque eles suportavam muito e resistiam à vontade de se matar. Da mesma forma, Unanue, por exemplo, distinguia a Lima "civilizada", livre de suicídio, de áreas rurais atrasadas, onde os indígenas pareciam se matar à vontade. Décadas mais tarde, O'Dea observou uma "influência encorajadora da civilização ao suicídio", um refrão familiar entre os que estavam convencidos de estar testemunhando epidemias de autodestruição branca. ${ }^{117}$ Embora a terminologia e as regras do jogo tivessem mudado, a suposição central permaneceu. O suicídio - seja na sua ausência ou na sua presença - continuou a servir como meio de marcar a superioridade branca.

Essa dinâmica estimulou o discurso nacionalista. Quatro séculos depois de Girolamo Benzoni ter escrito que os nativos cubanos "ansiavam pela morte", Lino Novás Calvo, romancista que muitas vezes pareceu obcecado pelo suicídio, culpou a independência tardia da llha, o caráter fraco e o pathos nacional pela inclinação suicida de seus habitantes originais, que "não eram uma raça forte e organizada". O suicídio, explicou ele, era "frequente" entre os nativos, cujo derrotismo tornava preguiçosos os conquistadores espanhóis e seus descendentes. Novas Calvo até encontrou "certa medida de alívio" no fato de todos os índios terem morrido. "A vitalidade de um povo", ele pensou, "é demonstrada no heroísmo e até mesmo no martírio, mas não no suicídio". ${ }^{118}$ Ao interpretar a imprecisa linha entre o martírio e o suicídio irresponsável em termos precisos, ele também separou os cubanos "reais" dos nativos.

\footnotetext{
117 Ibidem, p. 197.

118 NOVÁS CALVO, Lino. El pathos cubano. In: CHACÓN Y CALVO, José María. (org.). Homenaje a Enrique Jos'e Varona en el cincuentenario de su primer curso de filosofía (1880-1930): Miscelanea de estudios literarios, históricos y filosóficos. La Habana: Secretaría de Educación, 1935. p. 211-226. p. 213, 214.
} 
Como Novás Calvo, embora tendo em mente objetivos diferentes, o ex-escravo Esteban Montejo usou o suicídio para explicar quem deveria contar como cubano. Em sua história de vida, publicada pela primeira vez em 1966, ele disse:

\begin{abstract}
Uma [história] que estou convencido de ser uma invenção, porque nunca vi uma coisa dessas... é que alguns negros cometeram suicídio. Antes, quando os índios estavam em Cuba, o suicídio de fato acontecia. Eles não queriam se tornar cristãos e se enforcavam nas árvores. Mas os negros não fizeram isso, eles escaparam voando... Os chineses não voaram, nem quiseram voltar para o seu próprio país, mas cometeram suicídio. ${ }^{119}$
\end{abstract}

Não teria sentido reduzir a notável declaração de Montejo a uma simples rejeição ou apropriação de narrativas anteriores. Por um lado, ele apreendeu estereótipos coloniais e os fixou diretamente em nativos e chineses. Por outro lado, ele também destacou implicitamente a incapacidade ou falta de vontade de outros em compreender as ações, experiências e perspectivas dos escravos. Aqueles escravos, insistiu Montejo, não cometeram suicídio e escaparam voando para casa. Este não era o suicídio patológico das imaginações europeias, mas sim um profundo ato de libertação. ${ }^{120}$ Dessa forma, ele usou o suicídio para delinear uma identidade e uma herança cultural e racial única, e para distinguir o negro do nativo e do chinês.

Antonio Chuffat Latour, autor afro-chinês nascido em 1860, na mesma época que Montejo, estava atrás de algo semelhante. Chuffat Latour colocou os coolies no coração de uma nação cubana mestiça e associou seus sacrifícios aos de escravos africanos. Destacou o sacrifício e as contribuições chinesas por meio de histórias de trabalho duro, castigo, morte e suicídio. ${ }^{121}$ Em uma plantation, ele escreveu, 14 "miseráveis chinos" se enforcaram em revide ao terrível tratamento que sofriam. Suas mortes foram indicativas do sofrimento e do sacrifício dos trabalhadores chineses que, como os escravos negros, ajudaram a construir Cuba. ${ }^{122}$ Chuffat Latour encontrou, assim, no suicídio, uma oportunidade de expor sua própria definição de cubanidade, que dependia das contribuições de chineses e outros "estrangeiros" que "ajudaram a enriquecer Cuba e a conquistar sua independência; com esse amor que nos une como irmãos, em busca do progresso e de todas as coisas boas para Cuba,

119 MONTEJO, Esteban. The autobiography of a runaway slave. Ed. Miguel Barnet, traduzido por Jocasta Innes. New York: Pantheon Books, 1968. p. 43-44.

120 Isso se assemelha a algumas das ideias expressas por ex-escravos e seus descendentes entrevistados nos Estados Unidos durante a década de 1930. SNYDER, op. cit., p. 157-166.

121 LATOUR, Antonio Chuffat. Apunte histórico de los chinos en Cuba. La Habana: Molina, 1927. LYUN, Lisa. The coolie speaks: Chinese indentured laborers and African slaves in Cuba. Philadelphia: Temple University Press, 2008.

122 LATOUR, op. cit., p. 36. 
nossa Pátria". ${ }^{123}$ Para ele, a autodestruição não era um sinal de diferença, mas sim uma expressão do lugar dos cubanos chineses no centro da história nacional.

As ideias de Chuffat Latour e Montejo sobre o suicídio - cada uma subversiva por diferentes razões - oferecem vislumbres tentadores dos pensamentos e das ideias patologizados por observadores brancos. Para esses dois homens, esclarecer quem era o suicida, sob que circunstâncias e em que direção, foi um exercício significativo. Para Montejo, "voar para casa" representava um meio de se apropriar e descartar seletivamente os tropos coloniais e de diferenciar os afro-cubanos da história chinesa e indígena. Para Chuffat Latour, a autodestruição representava algo mais - não diferença, mas compartilhamento de sacrifícios e ligações fraternais mestiças. As palavras de ambos os homens nos lembram que a resistência era apenas um dos muitos significados racializados do suicídio e dos muitos significados e histórias de raça e suicídio ainda a serem explorados.

As ideias de Chuffat Latour e Montejo também se debruçaram sobre os juízos predominantes no hemisfério, incluindo a crença cada vez mais popular de que a civilização não dissuadiu o suicídio e, ao invés disso, "o fomentou". Isso não era inteiramente novo. Elites em todo o mundo definiram a autodestruição, num momento ou noutro, como um mal "moderno". ${ }^{124}$ Essa convicção, no entanto, produziu resultados únicos na América Latina, em fins do século XIX e início do século XX, especialmente quando entrou em contato com ideias evolucionistas sobre raça e nação. No Peru, estudiosos de medicina e direito descreveram o suicídio como um flagelo da modernidade e um sinal de degeneração moral e racial, mais bem confrontado por projetos de controle social baseados na eugenia. ${ }^{125} \mathrm{~A}$ Liga Brasileira de Higiene Mental classificou os suicidas juntamente com delinquentes, alcoólatras, prostitutas, negros, imigrantes e outros "elementos" degenerados da sociedade. ${ }^{126}$ Peruanos e brasileiros de elite podem estar se matando em grande número, argumentaram os estudiosos, mas as origens do problema e o verdadeiro perigo estão nas subclasses negras de cada nação.

Menos consternados do que os eugenistas, mas muitas vezes reproduzindo ideias semelhantes, eminentes estudiosos da América afro-latina comentaram a relação entre raça, suicídio e civilização. Fernando Ortiz, um dos pensadores mais

\footnotetext{
123 Ibidem, p. 11.

124 KUSHNER, Howard I. Suicide, gender, and the fear of modernity. In: WEAVER; WRIGHT, op. cit. p. 19-52. MINOIS, op. cit., p. 59.; WRIGHT; WEAVER. Introduction, op. cit., p. 8.

125 DRINOT, Paulo. Medico-legal and popular interpretations of suicide in early twentieth-century Lima. In: WEAVER; WRIGHT, op. cit, p. 178-180.

126 LOPES, op. cit., p. 106. REIS, José Roberto Franco. Higiene mental e eugenia: o projeto de "Regeneração Nacional" da Liga Brasileira de Higiene Mental (1920-30). 1994. Dissertação (Mestrado em História) - Universidade Estadual de Campinas, Campinas,1994. p. 25.
} 
influentes de Cuba no século XX, recebeu uma carta, em 1905, de seu mentor Cesare Lombroso, em que o parabenizava por uma recente publicação e solicitava que Ihe enviasse seu recente trabalho sobre o suicídio negro. ${ }^{127}$ Seguindo testemunhos de escritores coloniais e do século XIX, Ortiz pintou um quadro familiar de uma disposição patológica em relação à autodestruição entre vários povos africanos. Num texto, ele descreveu dois grupos de escravos calabari: um, cujos membros tinham contato frequente com brancos e eram "mais civilizados", e, o outro, um grupo mais isolado, que era "inferior", "violento", "vingativo" e "frequentemente inclinado a cometer suicídio". ${ }^{128}$ Ortiz também argumentou que os escravos africanos que se matavam para fugir do trabalho poderiam ter aprendido a prática com os índios. Para fazer a afirmação, Ortiz transpôs o espaço, citando como prova de sua suposição a passagem de um texto sobre a história cubana, que descrevia como a "inclinação para a preguiça e a indolência" dos nativos dos Andes levou-os a se matarem em grande número. ${ }^{129}$ Como O'Dea, que transpôs tendências suicidas brasileiras para a América Central, Ortiz colheu provas sobre o suicídio cubano nos Andes, nesse caso dando dois saltos: não apenas sugerindo que os escravos africanos poderiam ter aprendido tendências suicidas dos nativos, mas também imaginando que as supostas inclinação dos andinos nativos poderiam, de alguma forma, representar a natureza dos povos indígenas em toda parte.

Ortiz pertencia a uma geração de pensadores latino-americanos que amenizou as reservas em relação à mistura racial, abraçando um cauteloso otimismo de que, em certas circunstâncias, as nações americanas poderiam extrair força e singularidade da herança não branca. Como Ortiz, o intelectual brasileiro Gilberto Freyre baseou-se, em grande medida (e frequentemente sem críticas), em fontes coloniais para suas próprias descrições do suicídio, que ele discutiu em seu texto monumental Casa-grande \& senzala, um livro que forneceu grande parte do lastro intelectual para o que mais tarde ficou conhecido como (o mito da) democracia racial, a ideia de que o Brasil fora moldado por uma forma de escravidão excepcionalmente benevolente, que acabou por produzir uma sociedade racialmente harmoniosa. ${ }^{130}$ Baseando-se em narrativas europeias e citando Alexander Goldenweiser, antropólogo nascido na Rússia, Freyre

127 ORTIZ, Fernando. Los negros brujos. La Habana: [s. n.], 2007. p. 1. BRONFMAN, Alejandra. Measures of equality: Social science, citizenship, and race in Cuba, 1902-1940. Chapel Hill, N.C.: The University of North Carolina Press, 2004. p. 46.

128 ORTIZ, Fernando. Hampa afro-cubana: los negros esclavos, estudio sociológico y de derecho publico. La Habana: Revista Bimestre Cubana, 1916. p. 60.

129 Ibidem, p. 392; COWLEY, Rafael (org.). Los tres primeros historiadores de la isla de Cuba. v. 1. La Habana: A. Pego, 1876. p. 33.

130 FREYRE, Gilberto. The masters and the slaves (Casa-grande \& senzala): A study in the development of Brazilian civilization. Tradução de Samuel Putnam. New York: Alfred A. Knopf, 1946. 
descreveu o mal de comer terra, o banzo e o suicídio como exemplos do que ele entendia ser uma verdade inatacável sobre raça e civilização: "E o que mata esses povos primitivos é perderem quase a vontade de viver, ...uma vez alterado o seu ambiente; quebrado o equilíbrio de sua vida pelo civilizado." ${ }^{131}$ Incorporando e também revisando ideias anteriores, Freyre atribuiu o suicídio africano ao colonialismo europeu, mesmo ao descrever os negros como "primitivos".

Se Freyre entendeu a civilização como uma força disruptiva, que levava os africanos a persistentemente desejar uma vida mais simples e mansa, outros sugeriram que essa ruptura muitas vezes não ocorria, deixando muitos negros num casulo de atraso que os protegia do suicídio. Por exemplo, o psicólogo afroamericano Charles Prudhomme, cuja obra foi lida e citada no Brasil, explicou as aparentemente baixas taxas de suicídio entre afro-americanos como produto de seu "nível primitivo". Satisfeitos com "meras necessidades animais", eles "não estavam sujeitos à tentação do sistema econômico instável do Ocidente, com sua consequente influência no crescimento da taxa de suicídios, como o grupo branco". ${ }^{132}$ Por muito tempo uma ameaça à riqueza e ao privilégio branco, o suicídio negro - na sua ausência - agora também reforçava discursivamente uma e outro.

Qualquer que seja a visão deles sobre a relação entre civilização e suicídio, os acadêmicos de todo o hemisfério usaram os relatos da América Latina colonial para defender seu ponto de vista. Um psicanalista rejeitou a noção de que a civilização fomentava o suicídio, baseando sua tese no "fato histórico estabelecido" registrado por Las Casas e Benzoni, que "relatou autenticamente" tendências suicidas entre os povos nativos da América Latina. ${ }^{133}$ Como o barro nas mãos de tantos escultores, o suicídio tornou-se tanto uma prática difundida entre os chamados povos primitivos, quanto um flagelo confinado aos redutos da riqueza e da civilização brancas.

A elasticidade das discussões racializadas sobre o suicídio é uma prova de perpetuação e simultaneidade da falta de fiabilidade e da longevidade dos mitos suicidas e, pelo menos em parte, um produto do próprio ato. A natureza da autodestruição levanta questões que os contemporâneos, e ainda menos os historiadores, não podem responder. Essa aberta continuidade tornou-se matériaprima potente nas mãos dos teóricos raciais, que trafegavam num mundo tão singularmente fungível e definitivo, que era possível atribuir, permanentemente,

\footnotetext{
131 Ibidem, p.181. GOLDENWEISER, Alexander. Race and culture in the modern world. Journal of Social Forces, v. 3, n. 1, p. 127-136, 1924.

132 PRUDHOMME, Charles. The problem of suicide in the American negro. Psychoanalytic Review, v. 25, n. 2 e 3, p. 187-204, 372-391, 1938. p. 191, 192.

133 lbidem.
} 
rótulos como "civilizado" e "selvagem", assim como as características associadas a esses rótulos mudavam livremente.

Até mesmo os traficantes e senhores de escravos, que evitavam africanos propensos ao suicídio, discordavam sobre quais mereciam essa denominação. Séculos depois, enquanto discutiam se os não brancos eram mais ou menos propensos a se matar, os acadêmicos compartilhavam uma compreensão semelhante de quem era civilizado e quem não era. Como muitos de seus antecessores, eles entendiam o suicídio como uma régua - melhor ainda, uma fita métrica flexível - para medir distinções raciais dentro e através das fronteiras nacionais. Seja ligando ou separando a branquitude e o suicídio, elevando Zumbi e silenciando Ajuricaba, ou embalando Cahuide numa história fictícia de inclusão nacional, as ideias sobre o suicídio ajudaram a demarcar as coordenadas raciais e geográficas que ainda existem na América Latina de hoje.

O suicídio também ajudou a animar algumas das mais potentes vidas após a morte da escravidão. A escravidão fez com que as pessoas falassem sobre o suicídio não apenas como uma questão moral, religiosa ou médico-legal, mas também como intrinsecamente financeira - uma ameaça às perspectivas de produtores e comerciantes e um obstáculo à produção. Mas as implicações aqui são ainda mais amplas. Como a escravidão e outras formas de trabalho forçado tornaram-se sistemas de valores globais dominantes, que determinavam quem contava como humano, a capacidade de perecer por conta própria tornou-se um meio de fazer essa determinação - e, ironicamente, de divorciar os regimes de trabalho das muitas vidas que eles consumiam. ${ }^{134}$

Embora a brutalidade do trabalho estivesse sempre como pano de fundo, os observadores fizeram da raça a causa da morte, transformando o suicídio em prova e produto das matrizes raciais do trabalho forçado: nativos frágeis deram lugar a africanos vigorosos e depois aos coolies, que podem ter se matado por causa de condições adversas, mas, ao tirarem suas próprias vidas, demonstraram suas patologias e inferioridades. $O$ fato de que ideias anteriormente aplicadas a indígenas e africanos transferiram-se facilmente aos asiáticos atesta ainda mais a durabilidade dos valores que sustentam a escravidão e a relação duradoura e firme entre raça, trabalho e suicídio. Em casos heroicos excepcionais, como os de Cahuide e Zumbi, o suicídio foi entendido não como um ataque às instituições econômicas coloniais, mas como um ato de sacrifício fundacional que, no caso de Zumbi de Palmares, poderia ser considerado a remoção de um obstáculo ao "progresso" e à "civilização".

134 Sou grato a Antoinette Burton por me ajudar a desenvolver esta questão. 
As ideias das épocas colonial e pós-independência prenunciaram as observações dos homens de letras e de ciência do século $X X$, que reverteram as definições anteriores de civilização e suicídio, ao mesmo tempo em que reproduziram antigas suposições sobre a superioridade branca. Como os observadores coloniais, cujas ideias moldaram as suas próprias, esses homens trataram o suicídio como uma expressão de distinção racial. Em última análise, e apesar das notáveis reviravoltas, inconsistências e grandes mudanças, o arquivo americano do suicídio reforçou os "interesses particulares" e as diferenças percebidas, que antes impulsionavam o colonialismo e a escravidão e ainda moldam nossa compreensão do passado.

Recebido em 30/08/2019

Aprovado em 02/10/2019 